\title{
Urban Microclimate and Outdoor Thermal Comfort of Public Spaces in Warm-Humid Cities: A Comparative Bibliometric Mapping of the Literature
}

\author{
Clarence Dissanayake ${ }^{{ }^{*}(\mathbb{D})}$, Udawattage Gamini Dharmagupthe Weerasinghe ${ }^{2}$ \\ ${ }^{1}$ Department of Architecture, University of Moratuwa, Katubedda, Sri Lanka \\ ${ }^{2}$ University of Moratuwa, Katubedda, Sri Lanka \\ Email: *dissanayakec.21@uom.lk
}

How to cite this paper: Dissanayake, C., \& Weerasinghe, U. G. D. (2021). Urban Microclimate and Outdoor Thermal Comfort of Public Spaces in Warm-Humid Cities: A Comparative Bibliometric Mapping of the Literature. American Journal of Climate Change, 10, 433-466.

https://doi.org/10.4236/ajcc.2021.104023

Received: August 30, 2021

Accepted: December 10, 2021

Published: December 13, 2021

Copyright $\odot 2021$ by author(s) and Scientific Research Publishing Inc. This work is licensed under the Creative Commons Attribution International License (CC BY 4.0).

http://creativecommons.org/licenses/by/4.0/

(c) (i) Open Access

\begin{abstract}
Intensified human population encourages urbanization changing the morphology and metabolism of urban environments, thus altering the local climate and outdoor thermal comfort (OTC) in public spaces. OTC is an increasingly urgent area of research for tropical climates. This study explores the literature from the Scopus database on urban microclimate and OTC in public spaces and contrasts the studies in warm-humid cities through a bibliometric mapping of literature. The adapted methodology includes; Bibliometric Search, Scientometric Analysis, and Content analysis using VOSviewer software to identify the evolution paths, gaps, and the most recent movement of OTC assessments in urban public spaces. Results reveal five evolution paths related to all climatic regions; 1) materials and cooling strategies, 2) simulation modeling and urban planning, 3) design parameters affecting thermal perception, 4) cooling effects of green infrastructure, and 5) thermal adaptation in urban design. Although urban morphology and vegetation have been received the highest attention respectively, only a few for blue infrastructure related to warm-humid cities. This review identified five research gaps; the impact of blue infrastructure on OTC, strategies to overcome the effect of reflective materials, vegetation configurations in street canyons with wind flow, OTC improvements in asymmetrical street canyons, and how local climate zone (LCZ) classification approach could be used for OTC assessments. Past empirical studies have revealed that urban vegetation, surface materials, and morphological parameters are of paramount importance. Yet, the urban blue infrastructure has not received adequate research. Recently, the attention of researchers has been drawn to strategies in improving OTC
\end{abstract}


using micro-meteorological simulation modelling to examine the impact of urban design interventions. Finally, comprehensive content analysis, bibliographic coupling based on documents, co-occurrence of all-keywords, are suggested for future bibliometric reviews. Finally, further research on recommended areas would assist decision-makers in planning and design to enhance livability by improving microclimate and OTC in urban spaces.

\section{Keywords}

Urban Microclimate, Outdoor Thermal Comfort, Public Spaces, Bibliometric Analysis, Warm-Humid Cities, VOSviewer

\section{Introduction}

Intensified human population encourages urbanization changing the morphology and metabolism of urban environments, thus altering the local climate of urban public spaces. Most issues in sustainable development in urban areas such as health, energy, carbon emission, have been attributed to the local climate of cities (Xue et al., 2020). Urban or rural spaces are categorized into seventeen local climate zones (LCZ) which are established on the fabric, land cover, structure (geometry), and metabolism of particular space (Stewart \& Oke, 2012). There are two types in the categorization as "built types" and "natural landscapes without artificial erections". Because of climate change and ambient temperature increases throughout the world, biometeorological assessments and outdoor thermal comfort (OTC) in urban spaces have received increasingly urgent attention (Mayer et al., 2008; Holst \& Mayer, 2011; Taleghani et al., 2015; Morakinyo et al., 2018; Venhari et al., 2019; Zaki et al., 2020; Manteghi et al., 2020; Wai et al., 2021). Currently, modeling techniques which have been improving over many years are introduced to analyze the biometeorology of the urban environments considering the local climate. However, majority of the current OTC assessment methods provide results only for specific meteorological conditions instead of long-term analysis (Acero et al., 2020). However, meteorological conditions cannot fully account for changes in subjective thermal comfort though it is a significant factor in OTC assessment (Nikolopoulou \& Steemers, 2003; Han et al., 2007).

Even though tropical urban environments are more vulnerable to heat stress and thermal discomfort, research in assessing human biometeorology in tropical climates is scarce. However, there have been several studies on urban design and landscape design parameters such as morphology, geometry, density, greenery, configurations with warm-humid climates (Johansson \& Emmanuel, 2006; Sharmin et al., 2015; Chow et al., 2016; Johansson et al., 2018; Yahia et al., 2018). It must be noted that a proper understanding of the microclimatic differences influenced by urban morphology and landscape design elements provides important insights for improving OTC, especially in hot-humid cities (Thani et al., 2013; Lee et al., 2016; Lee \& Mayer, 2018; Lee et al., 2020). Microclimate investi- 
gations relating to urban designs have become broadly focused in different climates in recent decades (Chatzidimitriou \& Yannas, 2017; Lamarca et al., 2018). Nevertheless, designing comfortable urban spaces are critical especially in tropical cities, (Givoni, 1992) due to high intensity of solar radiation. Increased heat gain and reduced evaporation make tropical outdoor spaces overheat and cause thermal discomfort (Thani et al., 2013). Conversely, well-being of the urbanites and indoor climate is also positively influenced by thermally comfortable outdoor environments encouraging people to use public spaces in warm countries (Johansson \& Emmanuel, 2006). Therefore, special research attention has been received in seeking strategies to improve the contemporary circumstances of urban microclimate changes (Taleghani, 2018). Muniz-Gäal et al. (2020) highlight the urgency of proper strategies to transform current urban designs into climatic responsive designs revealing suitable methodologies, integrated tools, and improved communication among planners and climatologists. Moreover, communication issues, administrative and political discouragement, lack of knowledge in the subject matters such as advanced methodologies and techniques (Eliasson, 2000) are significant drawbacks in climate-responsive urban design practices. Therefore, the knowledge-base in urban climatology, microclimate, and OTC require enhancement revealing directions for further research and convincing the decision-makers of their advantages.

This study intends to explore the existing knowledge-base in the domain of urban microclimate and thermal comfort in public spaces, to compare the same in tropical cities through a bibliometric mapping and analyze them systematically. Mathematical analysis of published documents extracted from a database can be quantitatively and statistically investigated on the basic properties, publication patterns, and use of documents of a research domain with bibliometric analysis (Agarwal et al., 2016; Mora et al., 2017). A large volume of bibliographical data and information analysis, visualization and graphical representation techniques, and literature mapping can become conveniently accessible with the aid of software programs due to the fast advancement in data mining (Meng et al., 2020). Although there is an increasing number of empirical studies that have analyzed urban microclimate, outdoor thermal comfort and its' impacts, investigations in tropical warm cities have received less attention. Therefore, it is important to understand the evolution of the literature, key authors, research gaps, methodologies, and future directions of this research domain.

VOSviewer software has been developed in the Netherlands by Van Eck and Waltman of Leiden University. This software can build networks of journals, researches based on co-citations, keyword analysis according to co-occurrences, and visualize the outcome in bibliometric networks (Waltman, Eck, \& Noyons, 2010; Eck \& Waltman, 2019). VOSviewer bibliometric mapping has been applied in various fields of research such as local climate classification (Xue et al., 2020), smart and regenerative urban growth (Peponi \& Morgado, 2020), mental health and well-being (Hernández-Torrano et al., 2020), fear of crime in urban envi- 
ronments (Kawshalya et al., 2020), construction safety research (Jin et al., 2019), urban street space and residents' health (Meng et al., 2020), and in international mobile library research (Zhao \& Shen, 2018). Therefore, Scientometric Analysis using VOSviewer software was adapted for the network analysis algorithms to comprehend the connectivity of the existing knowledge in the domain of urban microclimate and thermal comfort of public spaces in warm-humid cities. The objectives of the study are as follows:

1) To identify influential authors, journals, countries, of the research domain of urban microclimate and thermal comfort related to all climatic regions.

2) To categorize the keywords and identify trends through an author keyword and co-occurrence analysis.

3) To compare the research attention received in warm-humid cities and provide the evolution paths, gaps, and latest movement of research advancement, through author keywords and document analysis.

\section{Methodology}

The research methodology has three main phases; Bibliometric Search, Scientometric Analysis, and Content analysis the approach of science mapping literature (Agarwal et al., 2016; Mora et al., 2017) was adapted to understand the research domain of urban microclimate and OTC in public spaces and compare the specific research attention received in warm-humid climate and the future directions. Figure 1 is a diagrammatical representation of the methodology.

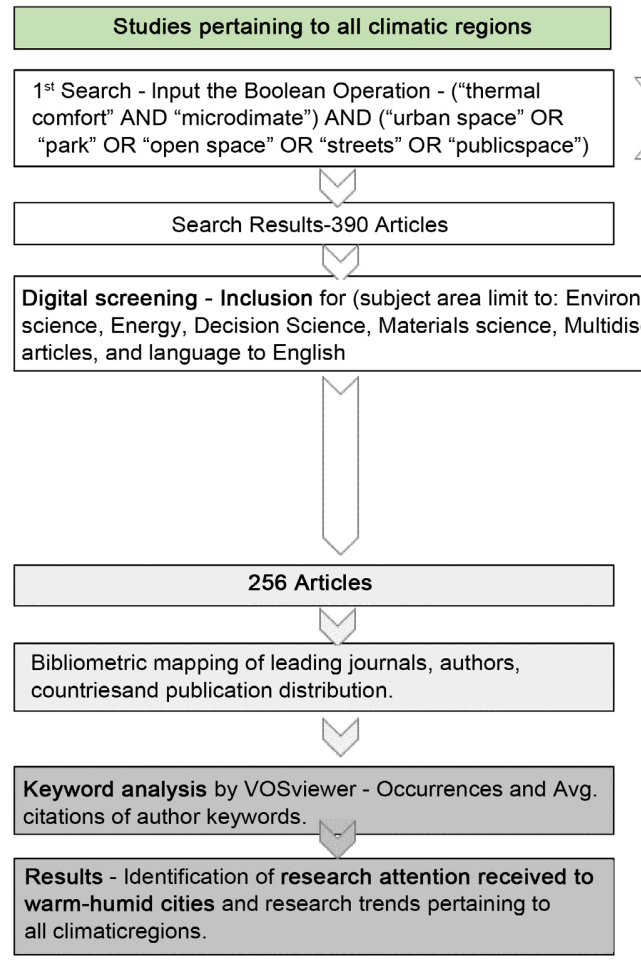

Figure 1. Summary of the methodology.
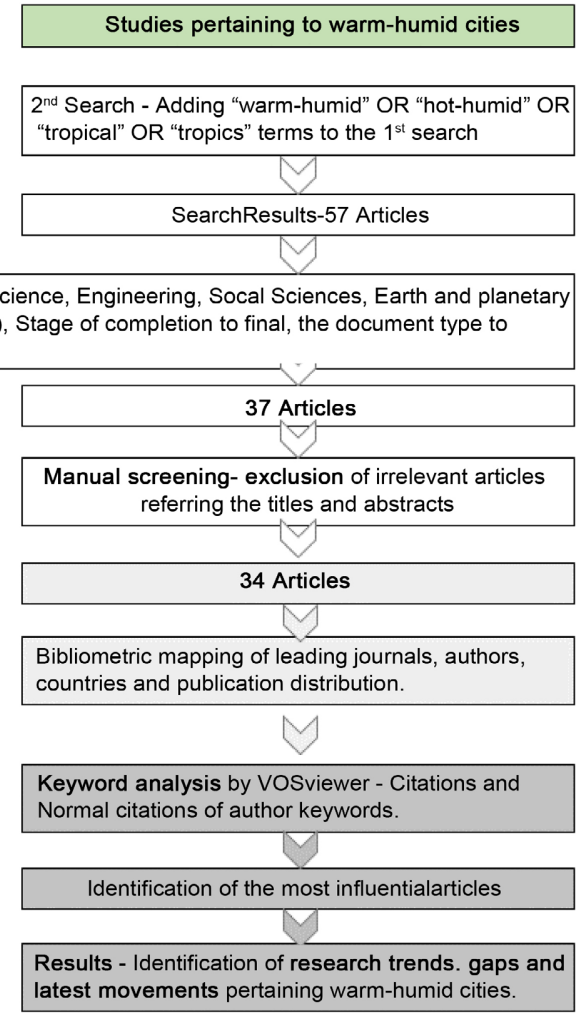


\subsection{Bibliometric Search and Data Acquisition-Phase I}

Bibliometric search was conducted based on Scopus database to explore the initial list of papers (csv format). The bibliometric data for the scientometric analysis is limited to only the one (Scopus) database, because of the inability to access several databases in a single analysis. Mongeon and Paul-Hus (2016) have mentioned that the Scopus database includes the largest number of exclusive journals in all fields and a lot more journals than Web of Science. Further, the Scopus database includes most of the articles indexed in Web of Science in both fields of Natural Science and Engineering, and Social Sciences. The retrieval of data was performed from the Scopus database in two searches, for the first search, the keywords used were "microclimate", "thermal comfort" and "urban public spaces". Thus, the following search procedure was conducted in the Scopus database. The retrieval of data was performed on 14 June 2021, and 390 bibliographic items with all information were exported. The inclusion of the publication comprises the year 1983 to 2021.

1st search-("thermal comfort" AND "microclimate") AND ("urban space" $O R$ "park" OR "open space" OR "streets" OR "public space”).

2nd search-("thermal comfort" AND "microclimate") AND ("warm-humid" $O R$ "hot-humid" OR "tropical" OR "tropics") AND ("urban space" OR "park" $O R$ "open space" $O R$ “streets" $O R$ “public space”)

The second search was conducted adding terms "warm-humid" OR "hot-humid" OR "tropical" OR "tropics" to the first search. The retrieval of data was performed on the same day and 57 bibliographic items with all information were exported. The inclusion of the publication comprises the year 1999 to 2021. Both searches were undertaken with digital filtering process. The manual screening was done only for the second search for further analysis. Article screening was carried out with inclusion and exclusion criteria. The digital screening was conducted with the initial inclusion of subject area to environmental science, engineering, social sciences, earth and planetary science, energy, decision science, materials science, multidisciplinary, and completion stage to final, the document type to articles, and language to English. Then, from the first and second search, 256 and 37 articles respectively were explored. In the manual screening, unrelated articles were excluded referring to the article title and the abstract of the paper in warm-humid cities of public spaces in tropical cities. Three (3) articles were removed in this process due to the irrelevance of the studies (semi-outdoor spaces, artificial neural network models, and ecosystem services).

\subsection{Scientometric Analysis-Phase II}

Scientometric analysis was conducted for acquired data from the bibliometric search and filtering process (256 articles from the first search and 34 from the second) using the version 1.6.15 of VOSviewer software, which quantifies and illustrates the relationships among scientific literature (Waltman, Van Eck, \& Noyons, 2010; Eck \& Waltman, 2020; Xue et al., 2020). It manifests the distribution of the publications, network of authors, journals, co-occurrence of key- 
words, co-citations, coupling and co-authoring relationships (Waltman et al., 2010). Temporal distribution, influential authors, contribution countries, author keywords were descriptively analyzed. The illustrations show the relationships among the selected articles creating a network using nodes and connections. The nodes visualize the importance of an item whereas the connections indicate the closeness among them (Eck \& Waltman, 2020; Tanudjaja \& Kow, 2018). In VOSviewer, the importance of an item is indicated by weight and score attributes. In visualization maps, an item with higher weight is displayed more prominently (with the size of the circles and labels) when compared with items of lower weights. Thus, the items with higher much weightages are highlighted with larger labels and circles.

\subsection{Content Analysis-Phase III}

A comprehensive quantitative analysis was conducted for the finalized (34) papers to identify the most influential papers on urban microclimate and thermal comfort in warm-humid cities. The document analysis was done using VOSviewer and ranked based on document weight and normal citation scores. Finally, a content analysis was conducted manually to determine the most recent movement, research gaps, and future trends in research advancement of urban microclimate OTC of public spaces in tropical cities. Although the scientometric analysis was limited to one (Scopus) database, the findings from content analysis were discussed referring to the most relevant literature from other scientific databases to validate the identified research gaps and trends.

\section{Performed Analysis}

This section shows the results of the scientometric Analysis and content analysis. This includes the illustrations of the evolution of the publications, leading journals, contributing counties, influential authors, and research topics by generating and clustering the citation network and Co-occurrence network for both 256 articles (analysis A) and 34 articles (analysis B) separately. Then, the selected publications were further reviewed manually to identify the extent of research attention received by the studies in warm-humid cities.

Analysis A-Studies of urban microclimate and OTC in urban public spaces irrespective of the climatic region with the search results of first bibliometric search.

Analysis B-Studies of urban microclimate and thermal comfort in urban public spaces in warm-humid climatic region with the search results of second bibliometric search.

\subsection{Analysis A-Outdoor Thermal Comfort Assessments in Urban Public Spaces}

\subsubsection{Evolution of Publications}

Article publications and citations of the articles in the particular domain of research represent the growth and the attention received by the articles. Figure 2 
shows the distribution pattern of the studies on microclimate and OTC in urban public spaces for the past 37 years. Two main stages were identified according to the article publication pattern from the year 1984 to 2021.

Obscured stage: from 1984 to 2005-limited research attention has been received and the average number of publication is 0.19 per year. It means that only 4 articles have been published during the 21 year period. One publication per several years is an indication that the area of research interest has not yet been established or noticeable.

Dynamic stage: from 2006 to June 2021-the research trend has started with 8 publications in 2006 and continuously the number of publications have been decreased until 2009. However, in the last decade (2010 to 2020), the number of publications has been steadily increasing until the average number of publications has reached 23.2 per year.

The number of research articles this research domain published in the Scopus database had been significantly increasing in the last decade. But there were minor fluctuations in the years 2012 and 2017. Overall, the results demonstrate that research attention on microclimate and OTC assessments in urban spaces is continuously increasing.

\subsubsection{Leading Journals}

Main contributing journals in the research domain of urban microclimate and OTC in public space, encompasses a large variety of subjects, such as urban science, meteorology, urban climatology, environmental science, cities and sustainability, building science, energy, landscape and forestry, and urban planning. Limitations were set to the minimum number of documents of a source as 3 and minimum citations as 15 to analyze the network of leading journals. The following overlay visualization in Figure 3 shows all the sources with 18 nodes and six clusters, the size of the scale of the circles represents the citation weights

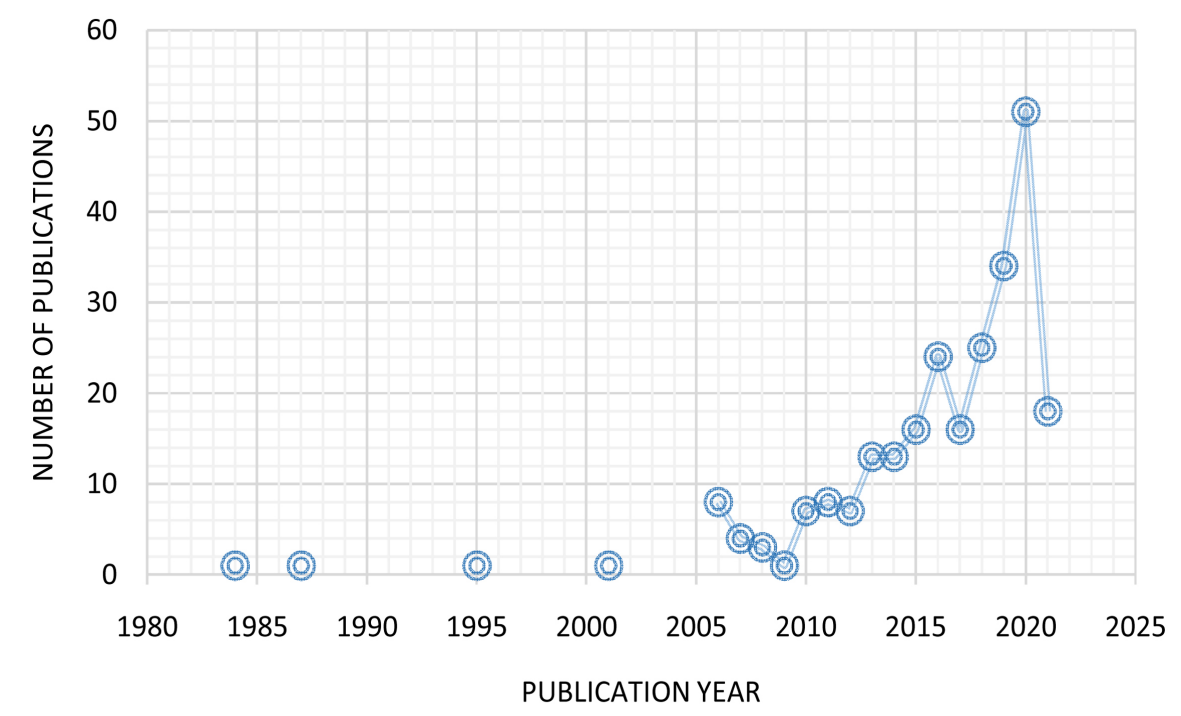

Figure 2. Publication pattern of the studies on OTC assessments in urban public spaces. 


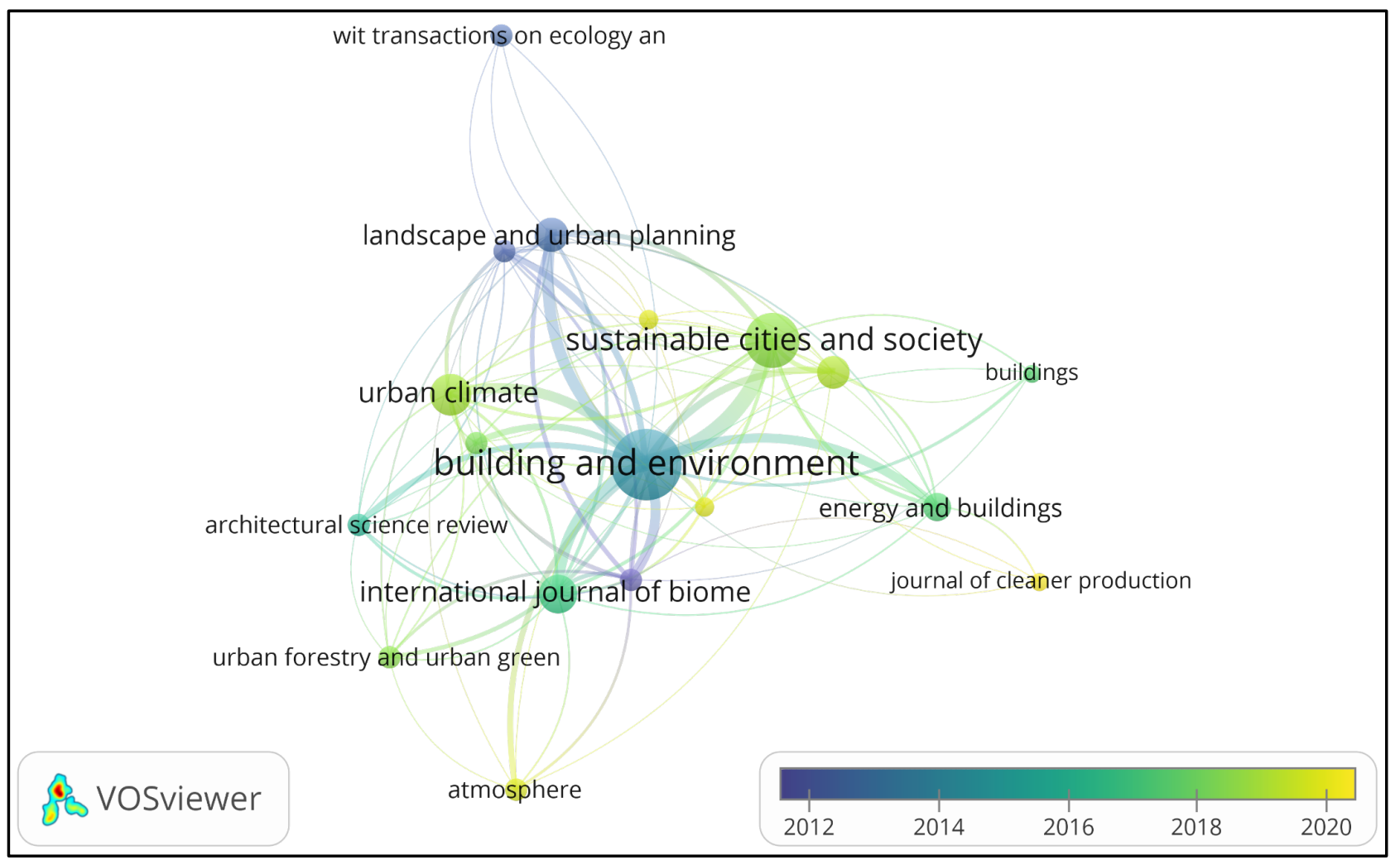

Figure 3. Overlay visualization of the leading journals on OTC assessments in urban public spaces.

and scores of average normalized citations per each journal.

According to the ranking based on the number of publications, Building and Environment published the most documents (46), followed by Sustainable Cities and Society and Urban Climate with 27 and 16 publications respectively. The link strength among the journals represents by the thickness of the connecting lines and the average normalized citations represents by the color (Eck \& Waltman, 2020). In between the Building and Environment and the Sustainable Cities and Society has the highest link strength (56), Building and Environment and International Journal of Biometeorology (36), and Building and Environment and Landscape and urban planning (35). These journals are actively citing each other showing the highest link strengths. Thus, Building and Environment journal has the highest total linking strength (307) in the studies on urban microclimate and OTC in public space, irrespective of the climatic region.

Table 1 quantitatively shows the ranking of the journals. Leading journals have been ranked according to the "average normalized citations" which is defined as the number of citations divided by the average number of citations published in the same year. This value modifies the misrepresentation that articled published earlier have more opportunity of being cited due to the time variations when compared with more recent articles. As such, the five most influential journals can be listed as Renewable Energy (2.5), Science of the Total Environment (2.0), Sustainable Cities and Society (1.7), Energy and Buildings (1.4), and the Building and Environment (1.3). The ranking of the fourteen most influential 
Table 1. Ranking of the leading journals based on average normalized citations.

\begin{tabular}{|c|c|c|c|c|c|c|c|}
\hline No. & Journal & $\begin{array}{c}\text { No. of } \\
\text { documents }\end{array}$ & $\begin{array}{l}\text { Total } \\
\text { citations }\end{array}$ & $\begin{array}{l}\text { Normal } \\
\text { citations }\end{array}$ & $\begin{array}{l}\text { Avg. } \\
\text { pub year }\end{array}$ & $\begin{array}{l}\text { Avg. } \\
\text { citations }\end{array}$ & $\begin{array}{l}\text { Avg. norm } \\
\text { citations }\end{array}$ \\
\hline 1 & Renewable Energy & 5 & 151 & 12.6 & 2018 & 30.2 & 2.5 \\
\hline 2 & Science of the Total Environment & 4 & 57 & 8.1 & 2020 & 14.3 & 2.0 \\
\hline 3 & Sustainable Cities and Society & 27 & 631 & 46.0 & 2018 & 23.4 & 1.7 \\
\hline 4 & Energy and Buildings & 8 & 412 & 11.8 & 2017 & 51.5 & 1.5 \\
\hline 5 & Building and Environment & 46 & 4769 & 62.7 & 2014 & 103.6 & 1.4 \\
\hline 6 & Solar Energy & 5 & 627 & 6.4 & 2013 & 125.4 & 1.3 \\
\hline 7 & International Journal of Biometeorology & 14 & 584 & 17.9 & 2017 & 41.7 & 1.3 \\
\hline 8 & Theoretical and Applied Climatology & 5 & 823 & 5.8 & 2010 & 164.6 & 1.2 \\
\hline 9 & Landscape and Urban Planning & 11 & 698 & 12.1 & 2013 & 63.5 & 1.1 \\
\hline 10 & Urban Forestry and Urban Greening & 5 & 129 & 5.0 & 2018 & 25.8 & 1.0 \\
\hline 11 & Urban Climate & 16 & 296 & 14.3 & 2019 & 18.5 & 0.9 \\
\hline 12 & Atmosphere & 5 & 34 & 3.7 & 2019 & 6.8 & 0.8 \\
\hline 13 & Journal of Cleaner Production & 3 & 18 & 2.1 & 2020 & 6.0 & 0.7 \\
\hline 14 & $\begin{array}{l}\text { International Journal of Environmental } \\
\text { Research and Public Health }\end{array}$ & 4 & 16 & 1.9 & 2020 & 4.0 & 0.5 \\
\hline
\end{tabular}

Note; the normal citation is the citation of all the articles within the same journal/Avg. pub year (Average publication year) is the average publication year of articles published in the given journal/Avg. citation (Average citation) is the total citations per article in the journal/Avg. norm citation (Average normalized citations) is the normalized number of citations of a journal, document, author, or an organization. It equals the total number of citations divided by the average number of citations published in the same year.

journals is shown in Table 1. when taking into consideration the average number of publication per year, it is revealed that the Journal of Cleaner Production, Science of the Total Environment, International Journal of Environmental Research and Public Health have been recently active in publication of the articles in this particular subject.

\subsubsection{Contributing Countries}

Contributing countries in terms of publications were analyzed setting the restrictions to the minimum number of publications of a country as 1 and minimum citations of a country as 100 . The following overlay visualization in Figure 4 shows all the countries with 22 items and 4 clusters. The size of the circles represent the document weights and the color represent the scores of average normalized citations. Since, the color of an item is determined by the score of the item, where by default colors range from blue (lowest score) to green to yellow (highest score) (Eck \& Waltman, 2020), yellow color indicates the country with the highest normalized citations. Accordingly, studies on urban microclimate and OTC in public spaces are mainly based on China (34), United Kingdom (27), Germany (26), Greece (22), and Australia (20) in terms of the number 


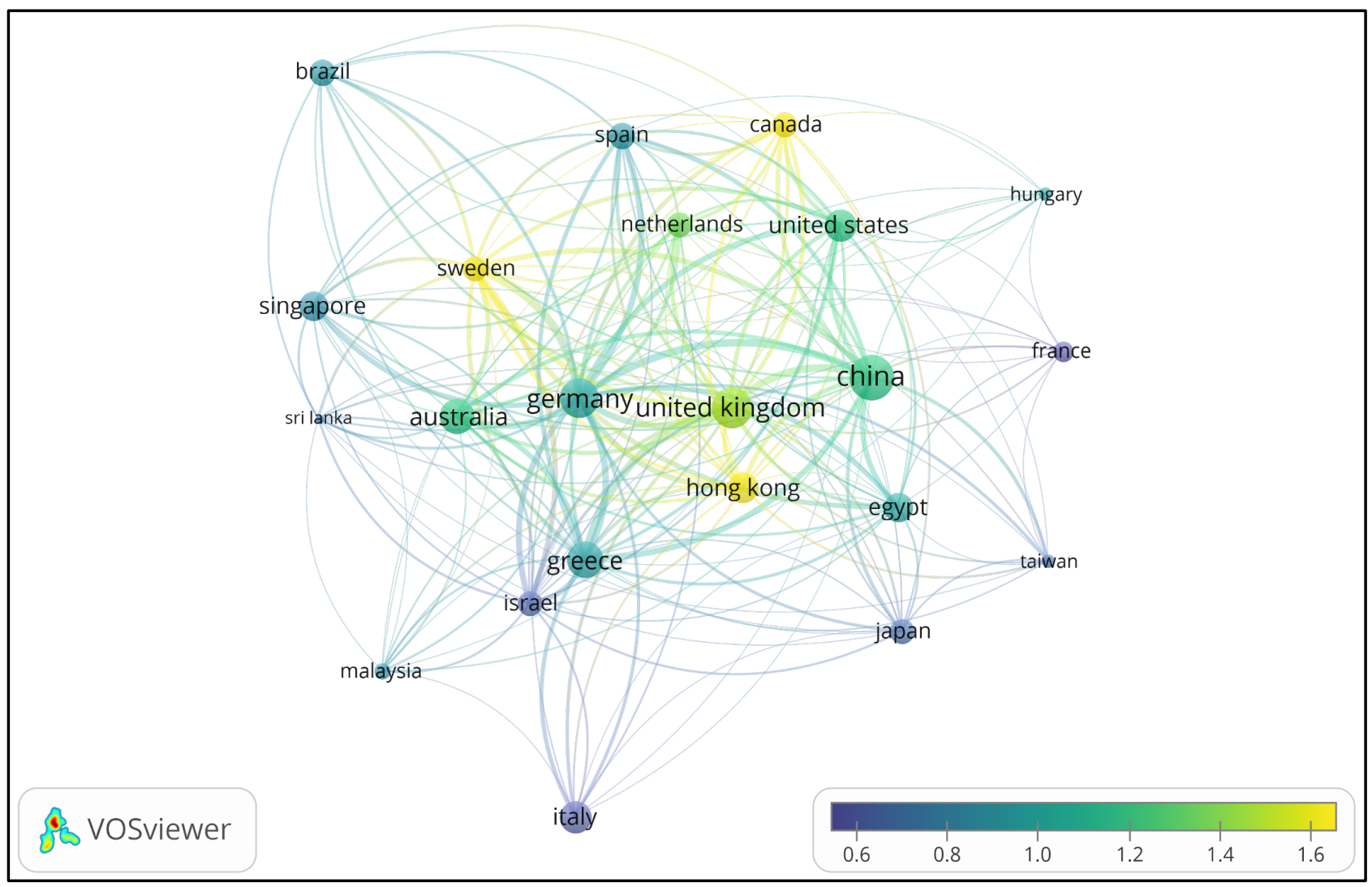

Figure 4. Overlay visualization of the most contributing countries and the number of documents on OTC assessments in urban public spaces.

of articles. According to the average normalized citations, Canada (2.01) has the highest influence on the research field. Moreover, Hong Kong (1.66), Sweden (1.65), Netherlands (1.33), and United States (1.19) have higher average normalized citations. It explains that, regardless of the year of publication, the most cited articles are from these countries. Considering the average number of publication a year, China (2018), Egypt (2018), and Hong Kong (2018) have the recent publication trend in this research domain. However, Sri Lanka has also published one document with 0.75 average normalized citations, 46 total link strength, and 235 citations which has considerable influence on the research field.

\subsubsection{Influential Authors}

Authors who make the highest contibution to this research domain were analyzed setting the restrictions to the minimum number of documents of an author as 1 and minimum citations of an author as 300 . The following overlay visualization in Figure 5 shows 22 items in four clusters. Since the citation weights and scores of average normalized citations are represented by the size and the color of the circles respectively (Eck \& Waltman, 2020), yellow colour indicates the author who has the highest normalized citations. Consequently, the most influential ten authors have been ranked in Table 2 across all countries. 


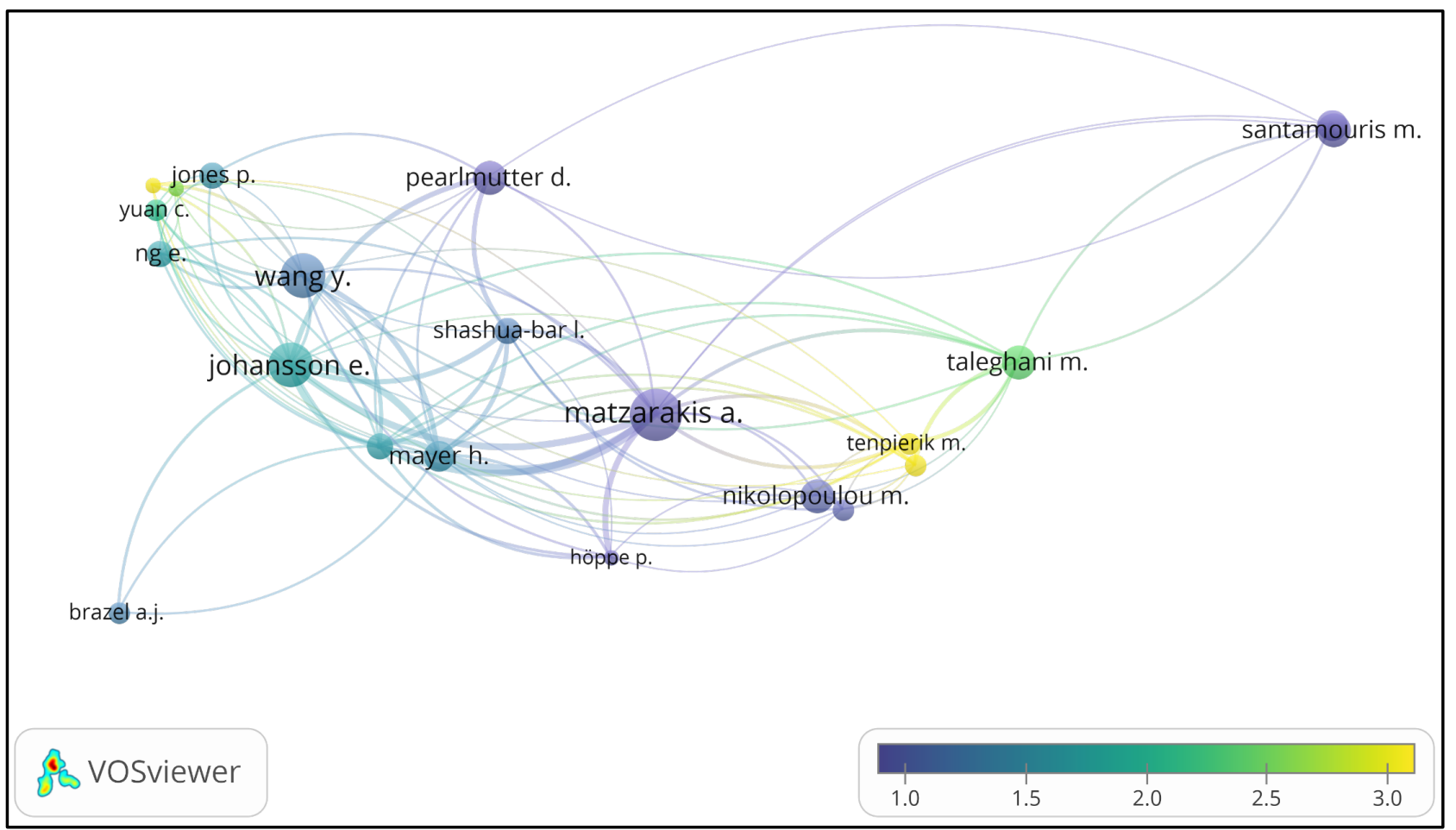

Figure 5. Overlay visualization of the most influential authors on OTC assessments in urban public spaces.

Table 2. Ten most influential authors ranked by average normalized citations in the domain of OTC assessments in urban public spaces.

\begin{tabular}{cccccccc}
\hline No. & Author & $\begin{array}{c}\text { No. of } \\
\text { documents }\end{array}$ & $\begin{array}{c}\text { Total } \\
\text { citations }\end{array}$ & $\begin{array}{c}\text { Normal } \\
\text { citations }\end{array}$ & $\begin{array}{c}\text { Avg. pub } \\
\text { year }\end{array}$ & $\begin{array}{c}\text { Avg. } \\
\text { citations }\end{array}$ & $\begin{array}{c}\text { Avg. norm } \\
\text { citations }\end{array}$ \\
\hline 1 & Alexandri e. & 1 & 434 & 2.5 & 2008 & 517.0 & 3.3 \\
2 & Tenpierik m. & 2 & 326 & 6.4 & 2015 & 163.0 & 3.2 \\
3 & Van den dobbelsteen a. & 2 & 326 & 6.4 & 2015 & 163.0 & 3.2 \\
4 & Chen I. & 1 & 517 & 3.3 & 2012 & 434.0 & 2.5 \\
5 & Teleghani m. & 5 & 471 & 11.9 & 2016 & 94.2 & 2.4 \\
6 & Yuan c. & 2 & 460 & 4.1 & 2015 & 230.0 & 2.1 \\
7 & Johansson e. & 8 & 867 & 13.9 & 2013 & 108.4 & 1.7 \\
8 & Ng e. & 3 & 487 & 5.0 & 2015 & 162.3 & 1.7 \\
9 & Ali-toudert f. & 3 & 974 & 4.9 & 2007 & 324.7 & 1.6 \\
10 & Jones p. & 3 & 621 & 4.6 & 2012 & 207.0 & 1.5 \\
\hline
\end{tabular}

\subsubsection{Research Topics-Keyword Analysis}

Scientometric analysis of author keywords was conducted for the first bibliometric search results from the Scopus database (256 bibliographic items) considering the co-occurrence and author keywords clustering. Bibliometric network of author keywords has been illustrated within the domain of urban microclimate and OTC in public spaces. The network visualization of co-occurrence analysis based on author keywords. Figure 6 has been illustrated setting the weight as 


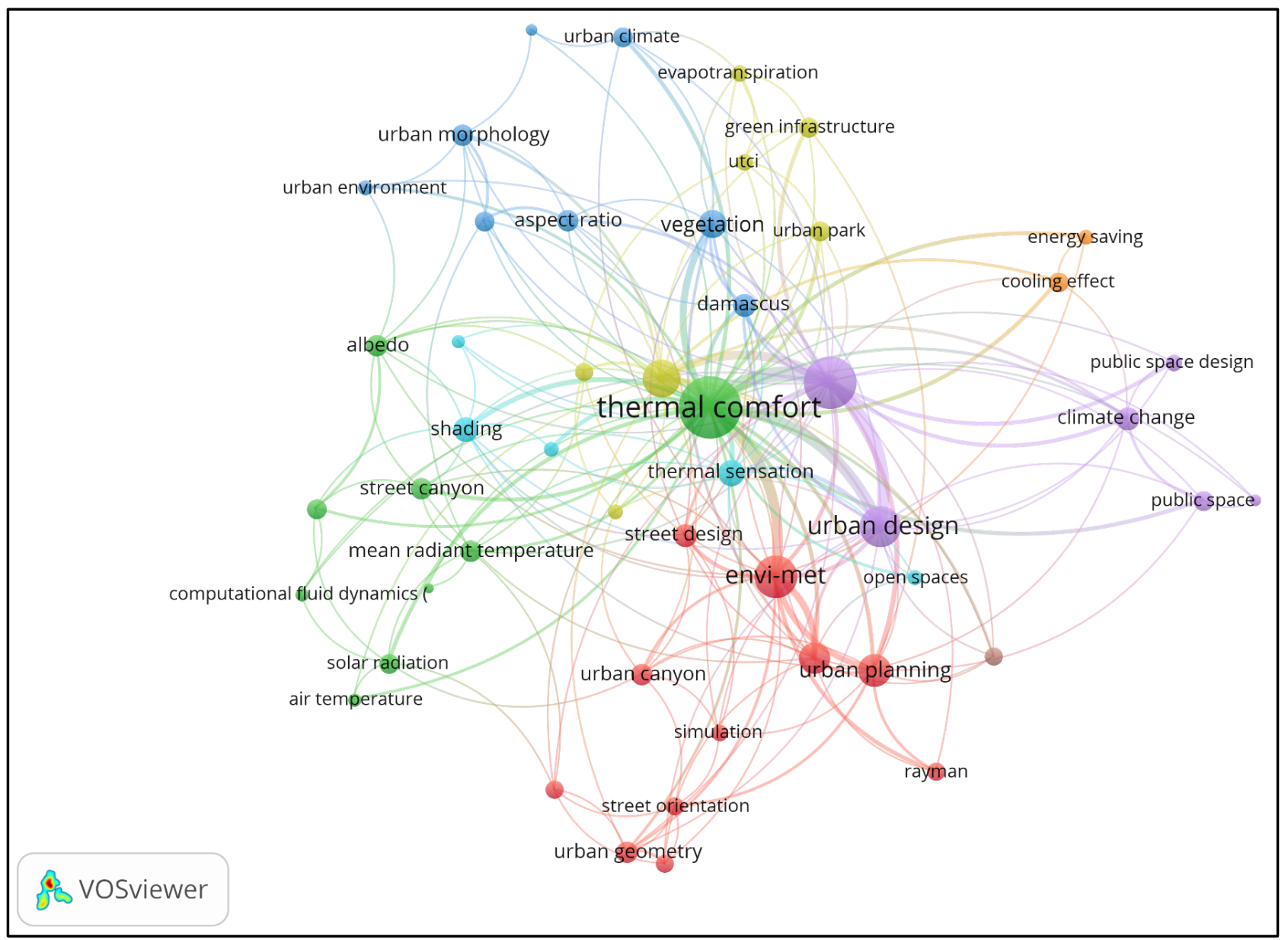

Figure 6. Network of co-occurrence analysis of author keywords showing total link strength, clusters, links and most connected author keywords in the domain.

total link strength to identify the clusters, links and most connected author keywords and number of occurrences in the research domain. Eight clusters including 49 nodes (author keywords) linked with co-occurrence links are shown in results.

The analysis of this section shows the frequency of appearance of keywords together and their frequency in the data set. The color of a node represents the cluster in which it is included and the nearness of the keywords represent their connection of each couple of terms. The higher the weight of an item, the larger the label and the circle of the item (Eck \& Waltman, 2020). Therefore, biggest circle represents the highest total link strength. Research trends could be identified by considering the clusters of keywords of the domain. Five pairs of keywords are identified based on the co-occurrence of the keywords. Thermal comfort and microclimate are ranked as the highest with link strength of 15. Further, microclimate and urban design with link strength of 12, thermal comfort and urban design with link strength of 11, thermal comfort and ENVI-met and microclimate and urban heat island (UHI) with link strength of 8 generally reveal that outdoor thermal comfort is highly impacted by urban microclimate and ur- 
ban design as the most linked/related part of the literature. Therefore, recent research papers are seeking strategies to improve thermal comfort in urban environments using micrometeorological simulation modeling.

The overlay visualization in Figure 7 shows the co-occurrence analysis based on author keywords and has been illustrated setting the weight as occurrences and scores as average citations to identify the most cited author keywords and number of occurrences in the research domain. Since the color of an item is determined by the score of the item, where by default colors range from blue (lowest score) to green to yellow (highest score) (Eck \& Waltman, 2020), this representation helps to identify the most influential and frequent author keywords in the domain.

It is evident that most attention in this domain has been drawn to the author keywords namely; urban design, urban canyon, physiological equivalent temperature (PET), thermal sensation, evapotranspiration, and ENVI-met simulations. This demonstrates that the studies assessing human bio meteorology in terms of the cooling effect of vegetation and the impact of street morphology have been widely investigated. Further, the adopted methodologies mostly comprise of computational fluid dynamics (CFD) for simulations and calculation of PET values as a thermal comfort index to assess the bio meteorology of outdoor thermal environments.

In urban bio meteorological assessments, several bio meteorological indices

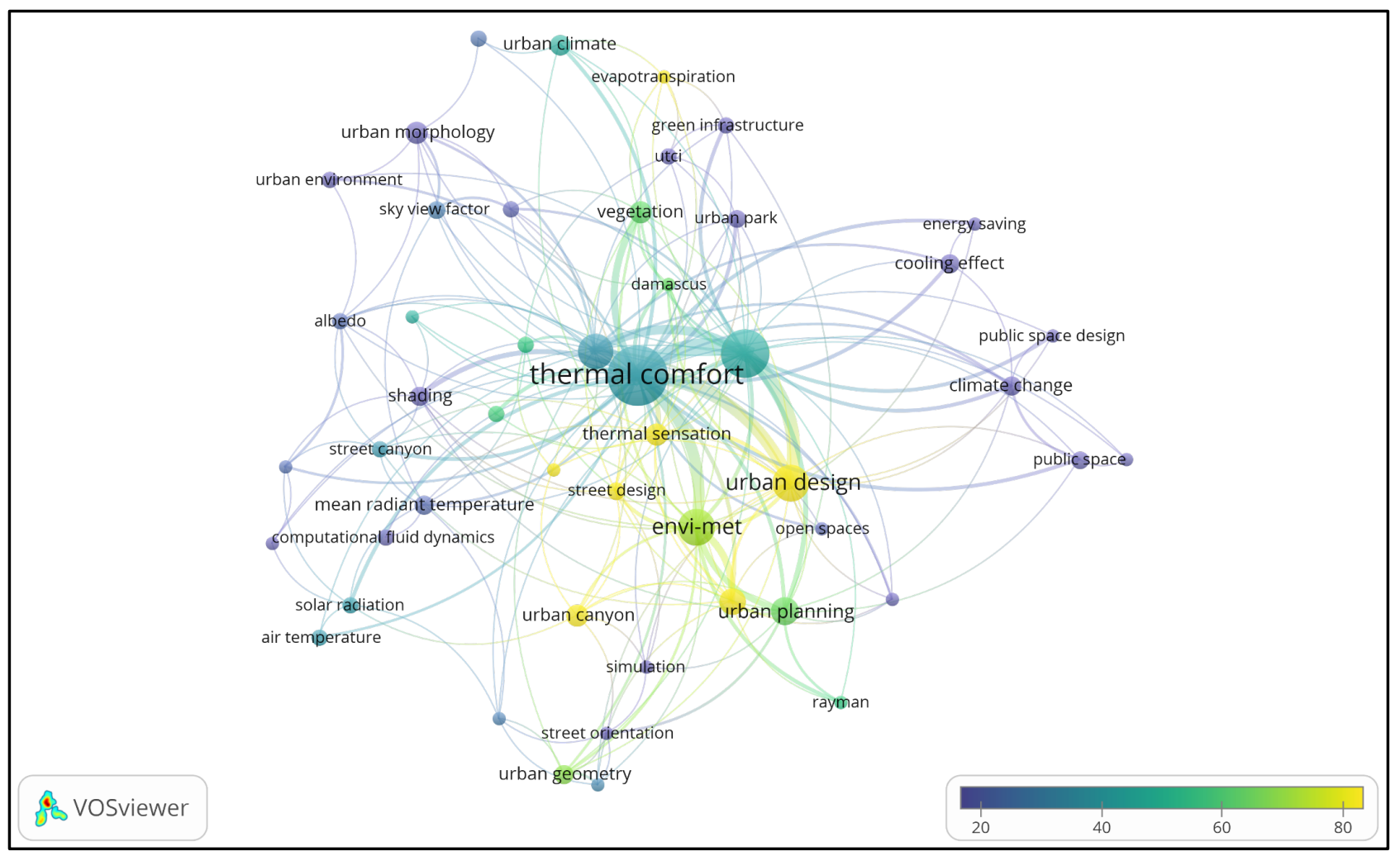

Figure 7. Overlay visualization of co-occurrence analysis of author keywords showing the most influential and occurred author keywords in the domain. 
have been introduced. Mayer \& Höppe (1987) have calculated predicted mean vote (PMV), skin wettedness and PET to calculate human thermal comfort in different urban environments. PET is a universal index for the bio meteorological assessment of thermal environment which is based on Munich Energy-balance Model for Individuals (MEMI) and it has been defined as equivalent to the air temperature in a typical indoor setting at which the heat balance of the human body is sustained (Hoppe, 1999; Matzarakis et al., 1999).

Table 3 shows the clusters of author keywords and the number of occurrences

Table 3. Clusters of author keywords with occurrences value and average of citation score.

\begin{tabular}{|c|c|c|c|c|c|}
\hline Cluster 1 (11 items) & Occurrences & Avg. citations & Cluster 2 (11 items) & Occurrences & Avg. citations \\
\hline Air temperature & 4 & 37.3 & Canyon aspect ratio & 3 & 32.0 \\
\hline Albedo & 4 & 24.5 & ENVI-met & 28 & 69.6 \\
\hline Computational fluid dynamics & 3 & 4.0 & PET & 13 & 87.8 \\
\hline Cool material & 3 & 46.0 & Rayman & 3 & 55.7 \\
\hline Evaporative cooling & 3 & 25.0 & Simulation & 3 & 11.3 \\
\hline Heat island & 4 & 87.5 & Street design & 5 & 95.4 \\
\hline Mean radiant temperature & 6 & 23.8 & Street orientation & 3 & 9.3 \\
\hline Shading & 6 & 19.3 & Urban canyon & 8 & 125.1 \\
\hline Solar radiation & 4 & 38.3 & Urban geometry & 6 & 66.7 \\
\hline Street canyon & 4 & 36.3 & Urban planning & 15 & 62.9 \\
\hline Thermal comfort & 84 & 39.0 & Warm humid climate & 3 & 29.3 \\
\hline Cluster 3 (8 items) & Occurrences & Avg. citations & Cluster 4 (7 items) & Occurrences & Avg. citations \\
\hline Aspect ratio & 4 & 21.8 & Evapotranspiration & 3 & 121.7 \\
\hline Sky view factor & 5 & 29.4 & Green infrastructure & 4 & 5.5 \\
\hline Thermal perception & 4 & 26.1 & Microclimate simulations & 3 & 79.3 \\
\hline Urban climate & 7 & 45.7 & Urban heat island & 24 & 36.6 \\
\hline Urban environment & 4 & 2.8 & Urban park & 5 & 18.2 \\
\hline Urban morphology & 9 & 15.7 & Urban vegetation & 4 & 55.8 \\
\hline Vegetation & 9 & 61.6 & UTCI & 4 & 17.0 \\
\hline Cluster 5 (5 items) & Occurrences & Avg. citations & Cluster 6 (4 items) & Occurrences & Avg. citations \\
\hline Climate change & 6 & 17.8 & Open spaces & 3 & 23.0 \\
\hline Microclimate & 51 & 44.4 & Outdoor spaces & 4 & 57.3 \\
\hline Public space & 5 & 7.6 & Thermal sensation & 9 & 104.7 \\
\hline Public space design & 3 & 18.0 & Urban design & 27 & 85.3 \\
\hline Thermal adaptation & 3 & 20.3 & & & \\
\hline Cluster 7 (2 items) & Occurrences & Avg. citations & Cluster 8 ( 1 items) & Occurrences & Avg. citations \\
\hline Cooling effect & 6 & 17.5 & Climate adaptation & 3 & 4.0 \\
\hline Energy saving & 3 & 19.3 & & & \\
\hline
\end{tabular}


(frequency of appearing in the data set). The first cluster contains 11 author keywords and presents about air temperature increases and thermal comfort. The top three keywords with the highest number of occurrences are thermal comfort which appears 84 times; mean radiant temperature 6 times and shading 5 times. The second cluster also contains 11 author keywords, signifying the micrometeorological modeling and urban planning approach, and the highest occurrences are ENVI-met 28 times; urban planning 15 times; physiological equivalent temperature (PET) 13 times. However, the term "warm-humid climate" belongs to the second cluster and receives 3 occurrences and 29.3 average citations. Thus, it seems that studies on thermal comfort and microclimate in warm-humid urban spaces have received the least occurrences and third-lowest average citations in this research trend. The third cluster has 8 author keywords presenting more factors affecting urban climate and the top three terms are, vegetation 9 times; urban morphology 9 times and urban climate 7 times. The fourth cluster includes 7 author keywords that present the urban heat gaining and cooling impacts of greenery. The top three terms are urban heat island 24 times; urban park 5 times and each urban vegetation, green infrastructure, and universal thermal comfort index (UTCI) 4 times. The fifth cluster includes 5 author keywords that present more about urban climatology in public spaces. The top three terms are microclimate 51 times; climate change 6 times and public space appeared 5 times. Then the sixth cluster includes 4 author keywords that present a more thermal perception-based urban design approach. The top three terms are urban design 27 times; thermal sensation 9 times; and outdoor spaces 4 times. The seventh and eighth clusters include 2 and 1 author keywords respectively that present energy and climate adaptation in urban spaces.

According to the number of occurrences and average citations belonging to each cluster, the literature could be categorized into five main research trends (clusters) as mentioned in Table 4. Though there are eight clusters, considering the number of author keywords in each cluster, five main research trends were identified and cluster six, seven, and eight are not considered due to lack of appearance of author keywords.

\subsection{Analysis B-Studies on OTC Assessments Conducted in Warm-Humid Urban Public Spaces}

The second search was conducted adding the terms "warm-humid" OR "hothumid" OR "tropical" OR "tropics" to the first search for which specific climatic regions were not considered.

\subsubsection{Evolution of Publications}

Article publications and citations of the articles represent the growth and the attention received in the particular domain of research. Figure 8 shows the distribution pattern of research publications on the microclimate and OTC in urban public spaces in warm-humid cities for the past 15 years. This research trend has started in 2006 and has been continuously growing with fluctuations with the 
Table 4. Identified evolution paths of the domain of OTC and microclimate in urban public spaces.

\begin{tabular}{cl}
\hline Cluster & \multicolumn{1}{c}{ Research trend } \\
\hline Cluster 1 & $\begin{array}{l}\text { Urban heat gain and ambient temperature increase as a result of } \\
\text { solar access and seeking strategies for thermal comfort using } \\
\text { cooling materials to reduce the heat island effect. }\end{array}$ \\
Cluster 2 & $\begin{array}{l}\text { Approaches for urban space design using micrometeorological } \\
\text { simulation modeling (ENVI-met) and comfort level (UTCI and PET) } \\
\text { improvements in urban planning processes. }\end{array}$ \\
Cluster 3 & $\begin{array}{l}\text { Parameters of urban morphology and vegetation affecting thermal } \\
\text { perception and urban microclimate. }\end{array}$ \\
Cluster 4 & $\begin{array}{l}\text { Urban heat gaining and cooling effects of greenery, vegetation, and } \\
\text { green infrastructure improving thermal comfort levels. }\end{array}$ \\
& $\begin{array}{l}\text { Thermal adaptation in public space design in terms of } \\
\text { microclimatic enhancement. }\end{array}$ \\
\hline
\end{tabular}

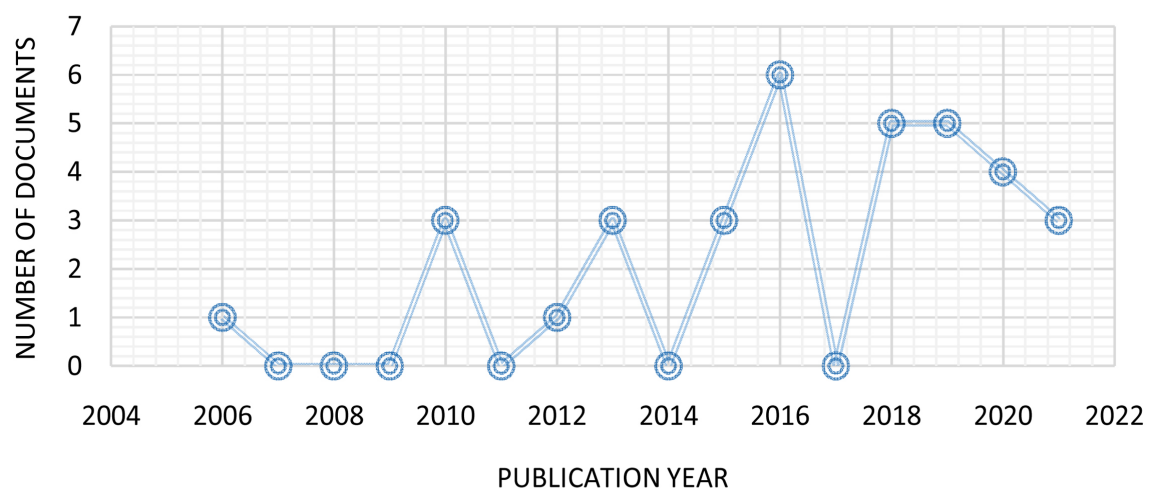

Figure 8. Publication pattern of the studies on urban microclimate and OTC in warm-humid urban public spaces.

year 2016 having the highest (6 articles) number of publications. However, this research area has not received considerable research attention from scholars, according to the number of publications during the last 15 years.

\subsubsection{Leading Journals}

Main contributing journals in the research domain of urban microclimate and OTC in warm-humid climates cover a range of subjects, such as climatology, meteorology, environmental science, cities and sustainability, urban science, and urban planning. Limitations were set to the least number of source documents and $t$ citations. The following overlay visualization in Figure 9 illustrates all the sources which were obtained with 15 items and five clusters. The size of the scale of the circles represents the document weights and the color represents the scores of average normalized citations per journal. Accordingly, the journal of Building and Environment is represented as the largest circle in yellow color as the most prominent journal. 
geographia polonica

buildings

international journal of biome

urban forestry and urban green

urban climate

landscape and urban planning

\section{building and environment}

\section{VOSvieweruildings}

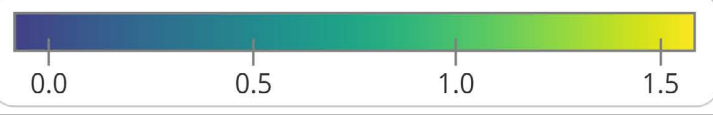

Figure 9. Overlay visualization of the leading journals of the studies of warm humid urban public spaces.

Table 5 quantitatively ranks the most influential journals with research in warm-humid cities according to scores of the average normalized citations. Consequently, the five most influential journals are Building and Environment (1.9), International Journal of Biometeorology (1.5), Urban Forestry and Urban Greening (1.4), Landscape and Urban Planning (1.0), and the Sustainable Cities and Society (1.0). The results show that the avg. publication year, the results show that the Journal of Sustainable cities and society, Energy and Buildings, Urban Climate, and Renewable energy are recently active in the publication of this particular subject. According to the results, $67 \%$ of the articles have been published after 2015.

\subsubsection{Contributing Countries}

The major contributing countries in terms of publication were analyzed setting the limitations to the least number of publications of a country and least citations of a country as 1 . The following overlay visualization (Figure 10) shows all the countries with 17 items and 5 clusters. The size of the circles represents the document weights and the colour represents the scores of average normalized citations. Studies on urban microclimate and OTC in warm-humid climates are mainly based on Germany (8), Singapore (7), United Kingdom (6), and Brazil, Indonesia, and Sweden (4) in terms of the number of documents. According to the average normalized citations, Finland and Ecuador (1.8) have the highest influence on the research field followed by Cuba and Spain (1.7), as the 
Table 5. The ranking of leading journals of the research in warm-humid urban public spaces.

\begin{tabular}{ccccccc}
\hline Journal & $\begin{array}{c}\text { No. of } \\
\text { Documents }\end{array}$ & $\begin{array}{c}\text { Total } \\
\text { citations }\end{array}$ & $\begin{array}{c}\text { Normal } \\
\text { citations }\end{array}$ & $\begin{array}{c}\text { Avg. } \\
\text { Pub year }\end{array}$ & $\begin{array}{c}\text { Avg. } \\
\text { citations }\end{array}$ & $\begin{array}{c}\text { Avg. } \\
\text { Norm } \\
\text { Citations }\end{array}$ \\
$\begin{array}{c}\text { Building and } \\
\text { Environment }\end{array}$ & 6 & 296 & 11.3 & 2017 & 49.3 & 1.9 \\
$\begin{array}{c}\text { International Journal } \\
\text { of Biometeorology }\end{array}$ & 3 & 327 & 4.5 & 2014 & 109.0 & 1.5 \\
$\begin{array}{c}\text { Urban Forestry and } \\
\text { Urban Greening }\end{array}$ & 2 & 80 & 2.8 & 2016 & 40.0 & 1.4 \\
$\begin{array}{c}\text { Landscape and } \\
\text { Urban Planning }\end{array}$ & 2 & 205 & 2.1 & 2011 & 102.5 & 1.0 \\
$\begin{array}{c}\text { Sustainable Cities } \\
\text { and Society }\end{array}$ & 1 & 8 & 1.0 & 2020 & 8.0 & 1.0 \\
$\begin{array}{c}\text { Energy and Buildings } \\
\begin{array}{c}\text { Urban Climate } \\
\text { Geographia Polonica }\end{array}\end{array}$ & 1 & 20 & 1.0 & 2019 & 20.0 & 1.0 \\
$\begin{array}{c}\text { Renewable Energy } \\
\text { Ren }\end{array}$ & 1 & 59 & 3.9 & 2018 & 14.8 & 1.0 \\
\hline
\end{tabular}

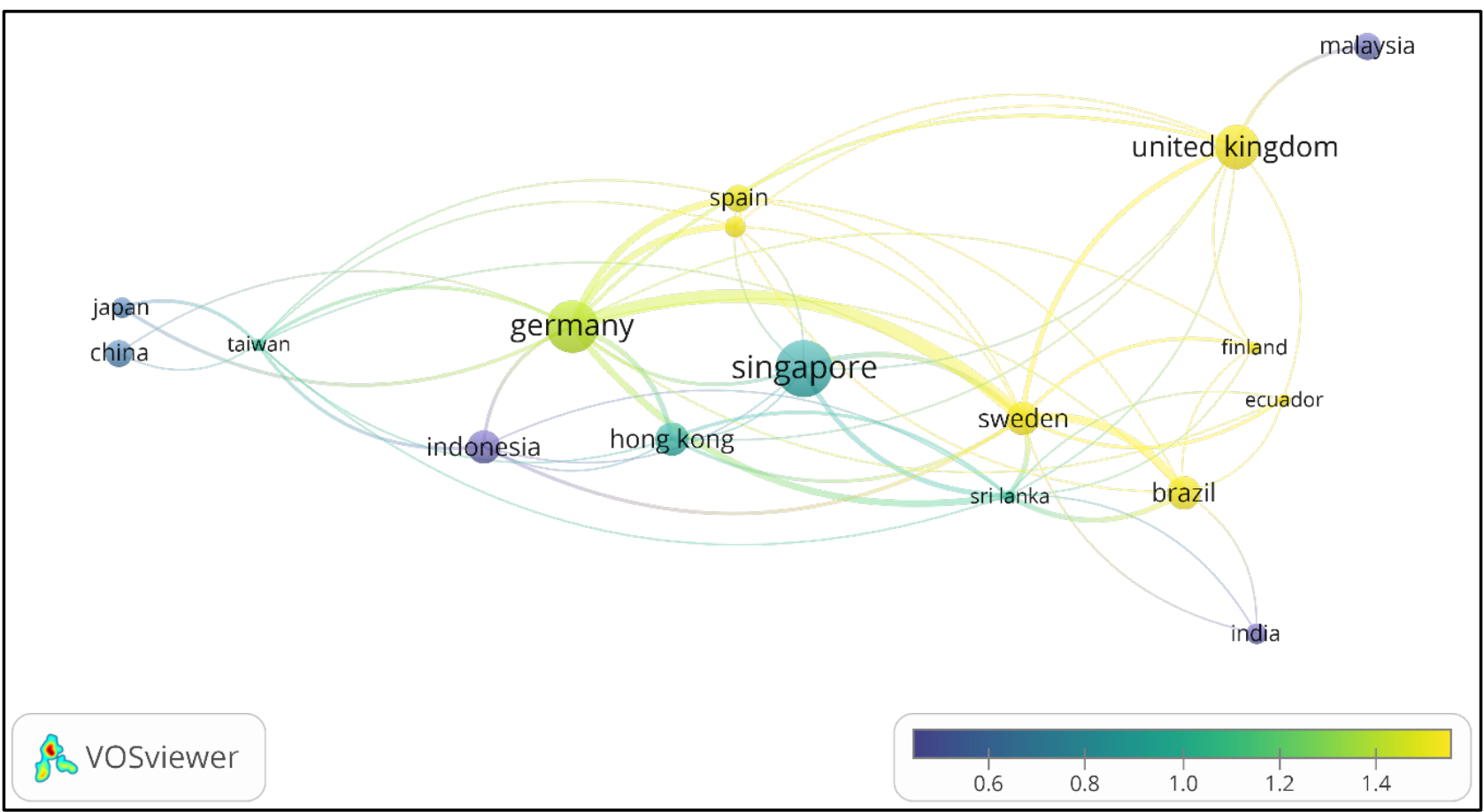

Figure 10. Contributing countries of outdoor thermal comfort studies in warm humid urban spaces.

second-highest and Brazil and Sweden (1.6) as third highest. Considering the average publication year, Hong Kong (2019), Singapore (2017), and Indonesia (2017) have the most recent publication trend in this research domain. However, 
Sri Lanka is the sixth in the ranking with 1.0 average normalized citations, 21 total link strength, 232 citations, and avg. pub. year as 2006 indicating considerable influence on the research field as the first article published in urban microclimate and OTC in warm humid climates.

\subsubsection{Influential Authors}

Figure 11 illustrates the most contributing authors in this research domain and limitations for this analysis were set to the least number of documents of an author as 1 and least citations of an author as 100. Results illustrated seven items in three clusters in the following overlay visualization. The size of the circles represents the citation weights and the color represents the scores of average normalized citations. Since the color of an item is determined by the score of the item, color range from blue to green to yellow (highest score), with yellow color indicating the author who has the highest normalized citations.

The six most influential authors (Table 6) across all countries who studied microclimate and OTC in warm-humid urban spaces. Johansson e. (1.6) ranked first with four documents, Matzarakis a. is the second most influential who published six documents avg. norm citations (1.4) records. Further, Emmanuel r., Tsai k.-t., Lin t.-p., and Hwang r.-l (1.0) published one paper by each of them. The recentness of the publications by a scholar represents by the average publication year. Thus, Matzarakis a. has the recent most influential publication after the year 2015.

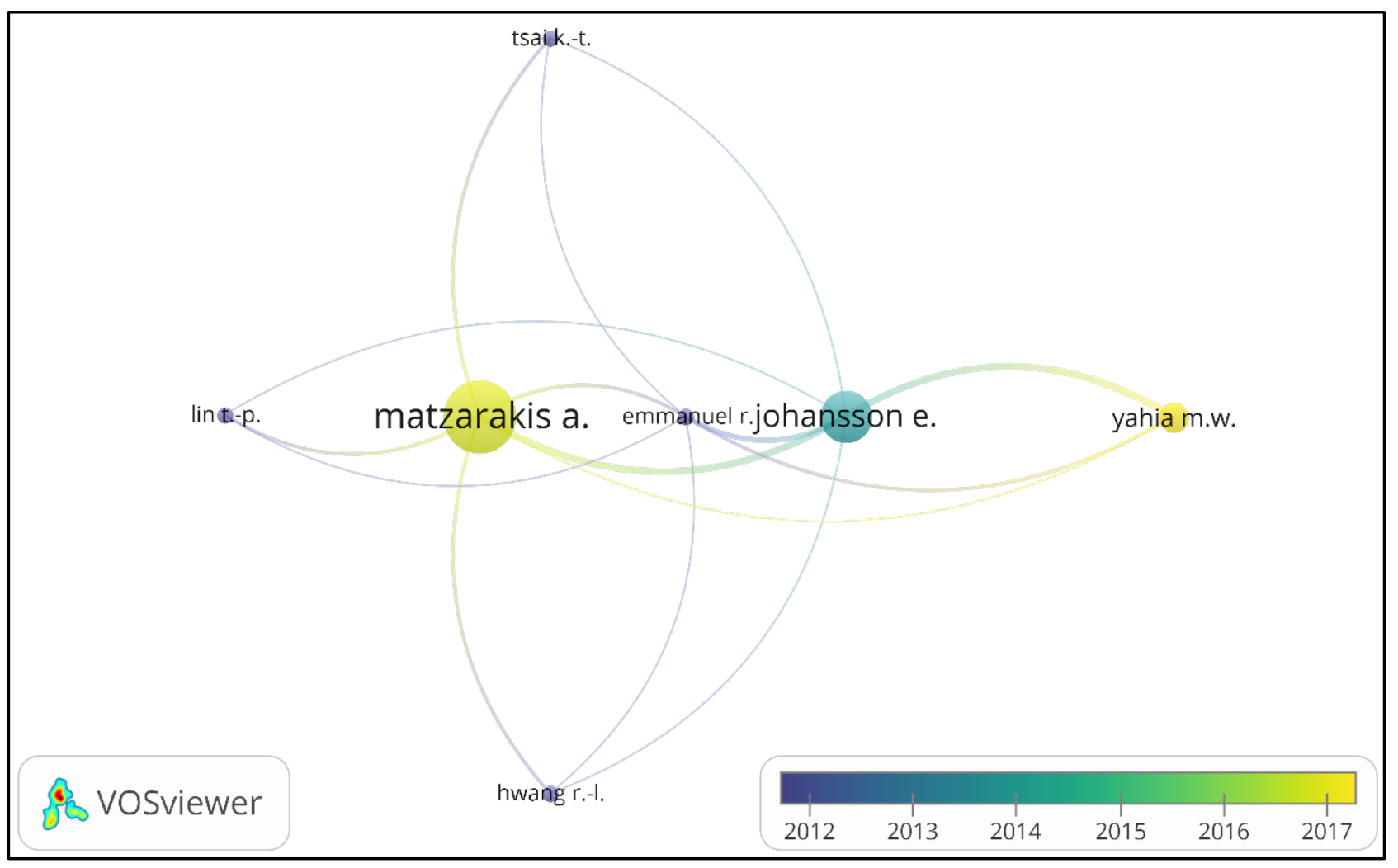

Figure 11. Most Influential authors of the studies conducted in warm-humid urban public spaces. 
Table 6. The most influential authors ranked by average normalized citations of the studies in warm-humid climates.

\begin{tabular}{ccccccc}
\hline Author & $\begin{array}{c}\text { No. of } \\
\text { documents }\end{array}$ & $\begin{array}{c}\text { Total } \\
\text { citations }\end{array}$ & $\begin{array}{c}\text { Normal } \\
\text { citations }\end{array}$ & $\begin{array}{c}\text { Avg. pub } \\
\text { year }\end{array}$ & $\begin{array}{c}\text { Avg. } \\
\text { citations }\end{array}$ & $\begin{array}{c}\text { Avg. norm } \\
\text { citations }\end{array}$ \\
\hline Johansson e. & 4 & 366 & 6.2 & 2013 & 91.5 & 1.6 \\
Matzarakis a. & 6 & 264 & 8.2 & 2017 & 44.0 & 1.4 \\
Emmanuel r. & 1 & 232 & 1.0 & 2006 & 232.0 & 1.0 \\
Tsai k.-t. & 1 & 117 & 1.0 & 2012 & 117.0 & 1.0 \\
Lin t.-p. & 1 & 117 & 1.0 & 2012 & 117.0 & 1.0 \\
Hwang r.-1. & 1 & 117 & 1.0 & 2012 & 117.0 & 1.0 \\
\hline
\end{tabular}

\subsubsection{Research Topics-Document Analysis}

The publications with the highest $t$ impact in the domain of the microclimate and OTC in warm-humid urban spaces (34 documents) were analyzed by the VOSviewer. Limitations were set to the least number of citations of a publication as 1 . The results yielded 20 documents in seven clusters as illustrated in Figure 12. Then the documents were ranked based on the normal citations as shown in Table 7. The content analysis has been conducted on 12 articles which are selected based on the normal citation above 1.00. Then each article was assessed and identified according to keywords and content analysis, because, the main focus and content of a study are represented by the keywords of the document considered within a specific knowledge domain (Su \& Lee, 2010).

According to Table 7, the most influential study was published in 2015, (normal citation 2.72, and 48 citations) which has focused on urban geometry in tropical hot-humid climates. The second most influential document (published in 2016, normal citations 2.56, and citations 73) was on urban morphology and street microclimates. The Article titled-urban geometry and the microclimate of street canyons in tropical climate, published in 2020, normal citations 1.94, and citations 15 has received the third highest which adapted ENVI-met modeling and PET in thermal comfort assessment. However, the most cited document is by Johansson E., Emmanuel R. published in 2006 titled "the influence of urban design on outdoor thermal comfort in the hot, humid city of Colombo, Sri Lanka" which has 232 citations and 1.00 average citations. The most recent publications have focused on the influence of urban morphology $(2018,2019$, and 2020), and blue infrastructure (2020) on microclimate, thermal comfort, and subjective thermal comfort (2018). Researches on urban vegetation have received fluctuated attention in 2012, 2013, and 2016. Further, first three most influential studies have investigated the effects of urban morphology parameters, while the studies on urban vegetation have received enough attention as the second most investigated factor. However, influence of blue infrastructure on thermal comfort and microclimate in tropical urban spaces has received less attention.

When comparing the studies related to all climatic regions, research in warmhumid climates require further enhancement focusing on different components 


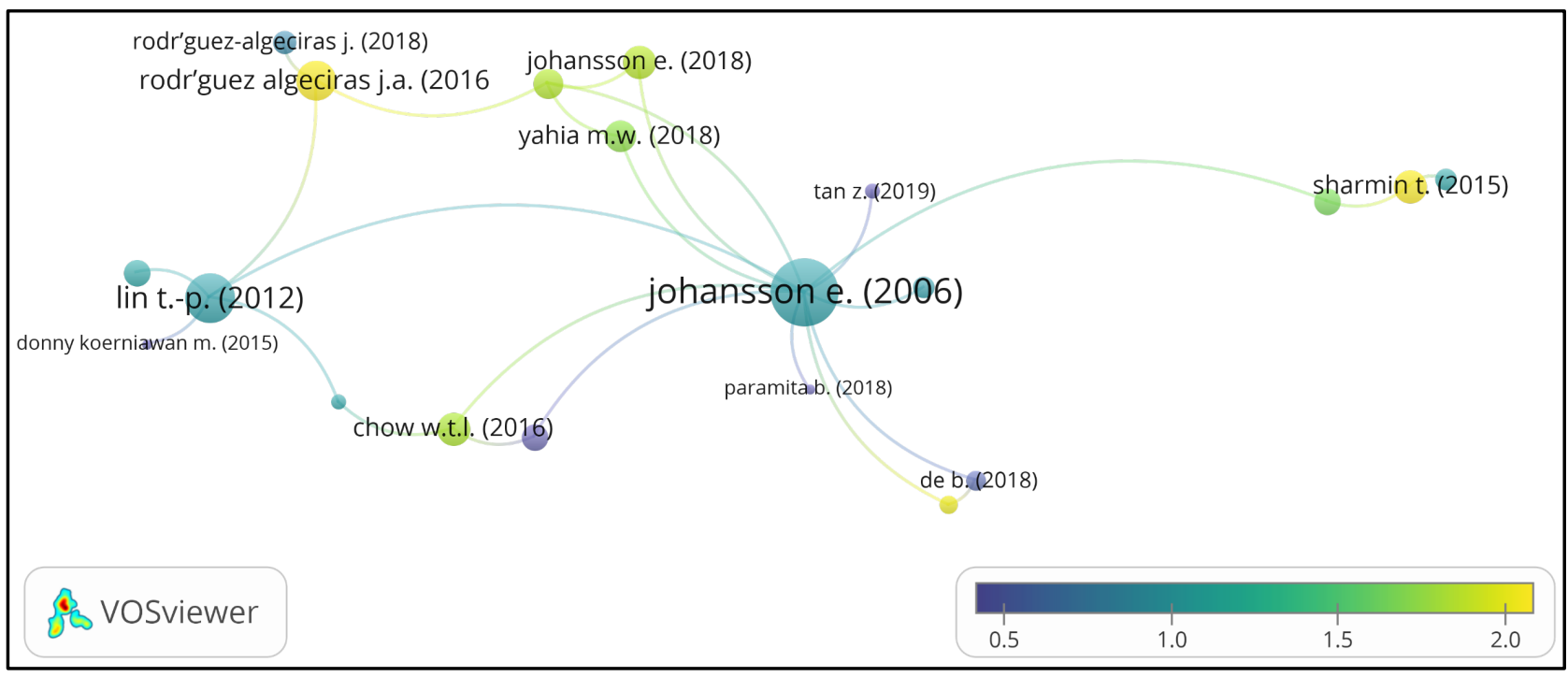

Figure 12. Overlay visualization of the most influential documents in warm humid urban public spaces.

of urban environments since the research trend had started in 2010 and is still fluctuating with only a few publications. However, studies on microclimate and OTC in urban spaces had commenced in 1984, and with the activation of the research domain in 2006, the publication of such articles in a large variety of journals has been continuously growing. Nevertheless, researches on warm-humid cities are still limited to a few countries and yet the authors in earlier stages of the publication timeline are the most influential in improving the research domain. The results revealed that urban morphology has received $50 \%$ of the total attention out of the total highest influential documents. Urban vegetation has received $33 \%$ and both impacts of water bodies and subjective thermal comfort assessment have received $8.3 \%$ of the most influential studies on microclimate and OTC in warm-humid urban public spaces. However, studies in warm-humid cities have considerable influence on the studies in other climatic regions. According to the most linked and frequent author keywords in this research domain, it is revealed that urban design parameters are significantly assessed to find the influence on OTC. Table 8 shows the urban design components and corresponding parameters assessed in 34 studies related.

\section{Findings and Discussion}

This review has revealed several urban design parameters that affect OTC and microclimate in pedestrian level, as discussed in previous sections. In this section, the results from content analysis of 34 studies in warm-humid climates are deliberated, referring to the most relevant literature from other scientific databases to validate the findings of previous sections of this review to confirm the research gaps.

Urban planners and environmental policy makers in different climatic regions have implemented several modifications of built environment altering surface materials, space morphology, irrigation systems and greenery with the objective 
Table 7. The list of most influential studies conducted in warm humid urban spaces with Publication year, title, and number of citations, normal citations, author keywords, and main focus and findings.

\begin{tabular}{|c|c|c|c|c|c|c|}
\hline No & $\begin{array}{c}\text { Authors \& } \\
\text { Year }\end{array}$ & Title & citations & $\begin{array}{c}\text { Norm } \\
\text { Citation }\end{array}$ & Keywords & Main focus and findings \\
\hline 1. & $\begin{array}{l}\text { Sharmin et al., } \\
2015\end{array}$ & $\begin{array}{l}\text { Analysis of microclimatic } \\
\text { diversity and outdoor } \\
\text { thermal comfort } \\
\text { perceptions in the } \\
\text { tropical megacity } \\
\text { Dhaka, Bangladesh }\end{array}$ & 48 & 2.72 & $\begin{array}{l}\text { Urban microclimate } \\
\text { urban geometry } \\
\text { outdoor thermal } \\
\text { comfort } \\
\text { tropical hot-humid } \\
\text { climate }\end{array}$ & $\begin{array}{l}\text { Morphology-Diverse } \\
\text { urban forms have positive } \\
\text { effect on OTC \& uniform } \\
\text { urban forms increase UHI, } \\
\text { traditional areas have lower } \\
\text { air and mean radiant } \\
\text { temperature than planned } \\
\text { areas, people in diverse } \\
\text { traditional areas perceive } \\
\text { more comfortable. }\end{array}$ \\
\hline 2. & $\begin{array}{l}\text { Algeciras et } \\
\text { al., } 2016\end{array}$ & $\begin{array}{l}\text { Spatial-temporal study on } \\
\text { the effects of urban street } \\
\text { configurations on human } \\
\text { thermal comfort in the } \\
\text { world heritage city of } \\
\text { CamagŸey-Cuba }\end{array}$ & 73 & 2.56 & $\begin{array}{l}\text { Human thermal } \\
\text { comfort } \\
\text { heritage urban centers } \\
\text { urban morphology } \\
\text { street microclimate } \\
\text { physiologically } \\
\text { equivalent } \\
\text { temperature (PET) }\end{array}$ & $\begin{array}{l}\text { Morphology-OTC at street } \\
\text { level, strongly affected by } \\
\text { aspect ratio and street } \\
\text { orientation. N-S orientation } \\
\text { is an effective strategy to } \\
\text { mitigate heat stress } \\
\text { in summer. }\end{array}$ \\
\hline 3. & $\begin{array}{l}\text { Muniz-Gäal } \\
\text { et al., } 2020\end{array}$ & $\begin{array}{l}\text { Urban geometry and the } \\
\text { microclimate of street } \\
\text { canyons in tropical } \\
\text { climate }\end{array}$ & 15 & 1.94 & $\begin{array}{l}\text { Urban street canyons } \\
\text { urban geometry } \\
\text { canyon aspect ratio } \\
\text { outdoor thermal } \\
\text { comfort } \\
\text { ENVI-met }\end{array}$ & $\begin{array}{l}\text { Morphology-OTC at } \\
\text { pedestrian level could be } \\
\text { improved by increasing H/W } \\
\text { in summer, but no significant } \\
\text { impact by lengthening the } \\
\text { canyon (higher L/H ratio), } \\
\text { Deep canyons increase } \\
\text { wind speeds and shading } \\
\text { from buildings. }\end{array}$ \\
\hline 4. & $\begin{array}{l}\text { Johansson et } \\
\text { al., } 2018\end{array}$ & $\begin{array}{l}\text { Outdoor thermal comfort } \\
\text { in public space in } \\
\text { warm-humid Guayaquil, } \\
\text { Ecuador }\end{array}$ & 49 & 1.79 & $\begin{array}{l}\text { Outdoor thermal } \\
\text { comfort, microclimate, } \\
\text { subjective thermal } \\
\text { comfort assessment, } \\
\text { warm-humid, climate }\end{array}$ & $\begin{array}{l}\text { Subjective thermal } \\
\text { perception-people accept } \\
\text { local thermal conditions } \\
\text { which are above acceptable } \\
\text { comfort limits in temperate } \\
\text { climates and the subjective } \\
\text { thermal perception varies } \\
\text { within a wide range. }\end{array}$ \\
\hline 5. & $\begin{array}{l}\text { Johansson et } \\
\text { al., } 2013\end{array}$ & $\begin{array}{l}\text { Scale-integrated } \\
\text { atmospheric simulations to } \\
\text { assess thermal comfort in } \\
\text { different urban tissues in } \\
\text { the warm humid summer } \\
\text { of Sao Paulo, Brazil }\end{array}$ & 39 & 1.77 & $\begin{array}{l}\text { Micro-scale modelling } \\
\text { meso-scale modelling } \\
\text { outdoor thermal } \\
\text { comfort } \\
\text { street trees } \\
\text { building density }\end{array}$ & $\begin{array}{l}\text { Vegetation-Non-shaded } \\
\text { areas exposed to solar } \\
\text { radiation is strong in heat } \\
\text { stress, low rise buildings } \\
\text { gives less shade and more } \\
\text { heat stress than high-rise. }\end{array}$ \\
\hline
\end{tabular}


Continued

\begin{tabular}{|c|c|c|c|c|c|c|}
\hline No & $\begin{array}{c}\text { Authors \& } \\
\text { Year }\end{array}$ & Title & citations & $\begin{array}{l}\text { Norm } \\
\text { Citation }\end{array}$ & Keywords & Main focus and findings \\
\hline 6. & $\begin{array}{l}\text { Chow et al., } \\
2016\end{array}$ & $\begin{array}{l}\text { Assessment of measured } \\
\text { and perceived } \\
\text { microclimates within a } \\
\text { tropical urban forest }\end{array}$ & 50 & 1.75 & $\begin{array}{l}\text { Urban parks, outdoor } \\
\text { thermal comfort, } \\
\text { tropical microclimate }\end{array}$ & $\begin{array}{l}\text { Street trees with medium } \\
\text { dense canopy greatly reduces } \\
\text { heat stress in the streets. }\end{array}$ \\
\hline 7. & $\begin{array}{l}\text { Yahia et al., } \\
2018\end{array}$ & $\begin{array}{l}\text { Effect of urban design on } \\
\text { microclimate and thermal } \\
\text { comfort outdoors in } \\
\text { warm-humid Dar es } \\
\text { Salaam, Tanzania }\end{array}$ & 46 & 1.68 & $\begin{array}{l}\text { Urban design, urban } \\
\text { microclimate, and } \\
\text { outdoor comfort, urban } \\
\text { morphologies, } \\
\text { warm-humid city }\end{array}$ & $\begin{array}{l}\text { Vegetation-Measured and } \\
\text { perceived thermal comfort } \\
\text { are found to be significantly } \\
\text { different, humidity and wind } \\
\text { conditions are potentially } \\
\text { critical for tropical thermal } \\
\text { comfort. }\end{array}$ \\
\hline 8. & $\begin{array}{l}\text { Lau et al., } \\
2019\end{array}$ & $\begin{array}{l}\text { Outdoor thermal comfort } \\
\text { in different urban settings } \\
\text { of sub-tropical } \\
\text { high-density cities: an } \\
\text { approach of adopting } \\
\text { local climate zone (LCZ) } \\
\text { classification }\end{array}$ & 31 & 1.50 & $\begin{array}{l}\text { Outdoor thermal } \\
\text { comfort local } \\
\text { climate zone } \\
\text { subjective thermal } \\
\text { perception } \\
\text { microclimatic } \\
\text { conditions } \\
\text { sub-tropical } \\
\text { high-density cities }\end{array}$ & $\begin{array}{l}\text { Morphology \& } \\
\text { vegetation-Low-rise } \\
\text { buildings create more } \\
\text { stressful urban spaces } \\
\text { compared to high-rise, trees } \\
\text { with high canopy density } \\
\text { improve OTC conditions, but } \\
\text { vegetation might negatively } \\
\text { affect the wind ventilation. }\end{array}$ \\
\hline 9. & $\begin{array}{l}\text { Fung and Jim, } \\
2020\end{array}$ & $\begin{array}{l}\text { Influence of blue } \\
\text { infrastructure on lawn } \\
\text { thermal microclimate } \\
\text { in a subtropical green } \\
\text { space }\end{array}$ & 8 & 1.03 & $\begin{array}{l}\text { Pond microclimate } \\
\text { waterbody } \\
\text { cooling effect } \\
\text { blue infrastructure } \\
\text { urban heat island } \\
\text { universal thermal } \\
\text { climate index } \\
\text { thermal comfort }\end{array}$ & $\begin{array}{l}\text { Morphology-People } \\
\text { perceive warmer sensation in } \\
\text { a compact or high-rise } \\
\text { setting, variations of urban } \\
\text { settings differently affect the } \\
\text { relationship between thermal } \\
\text { stress and subjective thermal } \\
\text { sensation, future research is } \\
\text { required determine how LCZ } \\
\text { classification system can be } \\
\text { applied at individual levels } \\
\text { and later to inform urban } \\
\text { design practices. }\end{array}$ \\
\hline 10. & $\begin{array}{l}\text { Hsieh, Jan, } \\
\text { and Zhang, } \\
2016\end{array}$ & $\begin{array}{l}\text { A simplified assessment of } \\
\text { how tree allocation, wind } \\
\text { environment, and shading } \\
\text { affect human comfort }\end{array}$ & 30 & 1.05 & $\begin{array}{l}\text { Wind environment, } \\
\text { and shading, } \\
\text { computational fluid } \\
\text { dynamics (CFD), } \\
\text { human comfort, } \\
\text { microclimate, standard } \\
\text { effective temperature } \\
\left(\text { SET }^{\star}\right) \text {, wind } \\
\text { environment }\end{array}$ & $\begin{array}{l}\text { Water bodies-Small shallow } \\
\text { pond has reduced air } \\
\text { temperature at downwind } \\
\text { lawn area by } 0.7^{\circ} \mathrm{C} \text { on a } \\
\text { sunny day, deeper and more } \\
\text { dynamic waterbodies could } \\
\text { be more effective being } \\
\text { incorporated with tree } \\
\text { shading and natural surfaces. }\end{array}$ \\
\hline
\end{tabular}




\section{Continued}

11. Lin et al., 2012 of thermal indices and sky view factor on park attendance

Johansson The influence of urban

12. and design on outdoor thermal Emmanuel, comfort in the hot, humid 2006 city of Colombo, Sri Lanka
Thermal comfort sky view factor park usage park attendance

Street canyon geometry, urban
Vegetation-OTC cannot be achieved without proper wind corridor design and human thermal comfort is mainly influenced by wind speed and shading.

Vegetation \& morphology-Increased SVF affects negatively on park attendance and it is proposed to use the averaged sky view factor (SVFa), instead of single-point sky view factor from fisheye photographs (SVFsp).

Table 8. Urban design components and corresponding parameters assessed in previous studies in warm-humid urban public spaces.

\begin{tabular}{|c|c|c|}
\hline No & Urban design component & Parameters investigated \\
\hline \multirow{3}{*}{1} & Urban surfaces & \\
\hline & Vertical & Albedo. \\
\hline & Horizontal & Albedo. \\
\hline 2 & Green infrastructure & $\begin{array}{l}\text { Plant area index (PAI), Location of trees, Leaf area density (LAD), The aspect } \\
\text { ratio of trees (ART), Canopy cover, Vegetation density, Planting patterns and } \\
\text { arrangement, Grass coverage, Tree species, facade greening, Tree type, } \\
\text { Canopy form. }\end{array}$ \\
\hline 3 & Morphology and geometry & Sky view factor (SVF), Street ratio H/W, Street axis orientations. \\
\hline 4 & Blue infrastructure & $\begin{array}{l}\text { Depth of the water body, Character (dynamic or still), Location of } \\
\text { the water body. }\end{array}$ \\
\hline
\end{tabular}

of facilitating comfortable outdoor spaces for urbanites (Morakinyo \& Lam, 2016). The identified urban design parameters have significant impact on urban bio-meteorology irrespective of the climatic region. According to previous review studies, changes of urban geometry, inclusion of vegetation, cool surface materials, and incorporated water bodies have been identified as four major mitigation strategies to improve OTC in urban areas (Lai et al., 2019). Additionally, Setaih et al. (2013, August) has identified five urban interventions, namely; shading elements, building arrangement with wind movement, cool surface materials, water sink techniques and tree planting and vegetation. Moreover, Wai et al. (2021) has claimed that building disposition, vegetation arrangement and shading elements and water spraying systems should be considered in improving OTC at pedestrian level. 
Although Yahia \& Johansson (2014) have highlighted urban space morphology, the orientation of elements, spaces and vegetation as three paramount factors that affect OTC level, urban surface is a determinant component influencing urban biometeorology. For instance, the level of thermal stress is highly affected by the location and the orientation of the urban surfaces due to amount of reflected solar directions in urban open spaces (Taleghani, 2018; Lee \& Mayer, 2018). Further, urban geometry and construction materials (Chatzidimitriou \& Yannas, 2015) and material properties affect the energy balance of surfaces (Doulos et al., 2004). Besides, the surface energy balance is affected by urban hydrological processes such as runoff, infiltration, interception, or irrigation of the urban areas and especially improve the OTC level during heatwave conditions. Even though, water bodies increase the humidity levels (Broadbent et al., 2018; Wai et al., 2021), it is an effect yet to be considered in climatic responsive urban designs. Therefore, this review concludes that urban biometeorology is affected by four main components of urban design interventions namely; urban surfaces (vertical and horizontal), morphology and geometry, green infrastructure and blue infrastructure.

Blue infrastructure in urban spaces has received the lowest attention as a strategy of improving the OTC level (Wai et al., 2021). Nevertheless, Setaih et al. (2013) claimed that use of water features is a good heat sink technique in improving the pedestrian thermal comfort in hot dry urban environments, but not a suitable heat sink for climates with high humidity conditions. According to Lai et al. (2019), the cooling effect of vegetation, cool surface, and water bodies are less in compacted urban space when compared to an open area. Therefore, implementation of the cooling strategy depends on climate zone and the surrounding characteristics of the urban space. Yet, water surfaces act in a positive way in urban thermal process with the evaporative cooling effect due to its' low reflectivity and high thermal inertia (Chatzidimitriou \& Yannas, 2015). Moreover, deep and dynamic water features partly shaded by trees could be a more effective way of reducing thermal stress (Fung \& Jim, 2020). Future tropical OTC studies should consider the critical aspects of local humidity and wind conditions (Chow et al., 2016). Thus, investigation of urban water bodies as a cooling strategy is still in need of further research in warm-humid cities due to high humidity and increased ambient air temperature.

Green infrastructure improve the microclimate by reducing hot air flows, evapotranspiration, and shading as the most efficient way to reduce the negative effect of warming urban environments (Bartesaghi et al., 2019). Trees are the most effective factor for reducing long-wave radiation exchange by blocking short-wave radiation penetration to the surface, while turf lawns and shrubs provide only the surface shading (Shashua-Bar et al., 2011; Ng et al., 2012). However, roof greening is not effective for human thermal comfort near the ground level ( $\mathrm{Ng}$ et al., 2012). The foliage density makes $60 \%$ of temperature regulation as the most effective determinant of urban vegetation (Morakinyo et 
al., 2018). According to the results of previous studies, the configuration of vegetation, mainly, arrangement, layout, type and location is crucial especially in streets to improve the OTC at pedestrian levels (De Abreu-Harbich et al., 2015; Hsieh, Jan, \& Zhang, 2016; Morakinyo et al., 2018; Zaki et al., 2020; Teshnehdel et al., 2020). Therefore, further research is needed to find the best vegetation strategies in terms of climatic responsive urban design, especially in tropical cities.

Assessing the impact of urban surface albedo on OTC has received considerable research attention. Although, the use of high albedo materials is an effective strategy to reduce heat stress (Fintikakis et al., 2011), there is a debate on selecting urban surface materials depending on the albedo value as the results of the previous empirical studies. The reason is that the law albedo materials increase surface temperature while the high albedo materials increase the ambient temperature due to high reflected radiation, which causes negatively on thermal comfort (Chatzidimitriou \& Yannas, 2015; Lee \& Mayer, 2018; Taleghani, 2018; Falasca et al., 2019). Moreover, surfaces with high reflective materials create longer hot hours in day time compared to low reflective ones (Lin et al., 2010). This should be overcome by identifying some cooling strategies that can reduce the negative effects of particular hard materials, since it is one of the major parameters of urban design.

Outdoor thermal comfort is influenced by due to altered alternative durations of incoming solar radiation and the mean radiant temperature (MRT) which is created by various urban forms (Taleghani et al., 2015). Urban morphology has been widely investigated in previous studies and this review has identified three main morphology parameters, namely; aspect ratio (H/W), sky view factor (SVF) and axis orientation of the spaces. Urban aspect ratio describes the building height $(\mathrm{H})$ to road width $(\mathrm{W})$ ratio. Aspect ratio and the orientation control the solar access into street canyons (Deng \& Wong, 2020). According to the results of previous research in tropical regions, increased $(\mathrm{H} / \mathrm{W})$ ratio gives more significant cooling benefits (Morakinyo et al., 2017; Deng \& Wong, 2020), as a result of due to the shade created by deeper canyons (Emmanuel et al., 2007). Moreover, the canyons with higher $\mathrm{H} / \mathrm{W}$ aspect ratios increase wind velocity and shading by improving thermal comfort at the pedestrian level. Nevertheless, the street length to building height $(\mathrm{L} / \mathrm{H})$ ratio had no significant effect on the thermal comfort level at the pedestrian level (Muniz-Gäal et al., 2020). Thus, the configuration of trees in street canyon is important, since trees act as a wind moderator (Hsieh, Jan, \& Zhang, 2016; Yahia et al., 2018). Although, the asymmetrical streets canyons are mostly available in tropical countries, thermal comfort assessments related to such streets has received very low research attention. However, symmetrical canyons in different climate zones have received adequate research attention.

The content analysis further reveals that the methodologies applied in assessing OTC in urban environments have two main approaches called; subjective 
thermal perception assessments and objective thermal comfort simulations. Adapted methodologies in subjective assessments comprise of micrometeorological measurements and instrumentation, questionnaire survey and interviews, and calculation of thermal comfort level using a bio meteorological simulation tool (Spagnolo \& De Dear, 2003; Ruiz \& Correa, 2015; Zhao \& Fong, 2017; Johansson et al., 2018). On examples related to warm-humid climate, Kumar \& Sharma (2021) have recently used objective and subjective measurements conducting onsite monitoring (microclimate parameters) and a questionnaire based on ASHRAE Seven-point sensation scale, and calculated both MRT and PET using RayMan Pro 3.1 software. Subjective data such as personal information, current activity, clothing type, thermal sensation scale, thermal preference have been obtained. Further, Mouada et al. (2019) conducted a questionnaire survey applying a 9-point scale of thermal sensation votes (TSV). However, Johansson et al. (2018) has used two thermal comfort indices; PET and the standard effective temperature $\left(\mathrm{SET}^{*}\right)$ to compare people's subjective thermal perception in urban outdoors. Sharmin et al. (2015) found that traditional areas have lower air temperature and MRT than planned areas and people in diverse traditional areas perceive more comfort when comparing subjective (using TSV) and calculated MRT. Another study conducted by Chow et al. (2016) has found significant differences between measured and perceived thermal comfort. Therefore, as highlighted by Ruiz \& Correa (2015), validation of the subjective approaches by quantifying thermal comfort levels using bio meteorological indices could be more rational to examine the local climate adaptation in urban spaces.

Adapted methodologies in objective approaches mainly comprise of two phases; 1) Onsite measurements of meteorological parameters, 2) numerical simulations. The meteorological parameters affecting thermal comfort; air temperature, humidity, wind speed, and wind direction are measured at the pedestrian level ( $1.5 \mathrm{~m}$ above ground level) in majority of the studies to ensure the pedestrian level thermal comfort. In recent studies, OTC is frequently estimated with parametric ENVI-met simulations employing physiologically equivalent temperature (PET) (Emmanuel et al., 2007; Muniz-Gäal et al., 2020; Fung \& Jim, 2020; Fabbri et al., 2020; Shareef \& Abu-Hijleh, 2020; Mahmoud et al., 2021; Wai et al., 2021). Further, the simulation results have been validated by onsite measurements in many studies. Therefore, Computational fluid dynamics (CFD) simulations validated by field measurements is recommended for OTC assessments in urban outdoor spaces.

Findings of the review and potential research gaps,

1) There is inadequate research on the impact of blue infrastructure on OTC irrespective of the climatic zone, and especially in warm-humid cities. Considering the use of water bodies, irrigation and water spraying systems is yet to be explored.

2) Heat mitigation strategies to overcome the increased ambient temperature due to reflective urban surfaces (high albedo) need to be investigated. 
3) Vegetation configurations in street canyons, and other critical areas in urban environments should be assessed taking ventilation into consideration.

4) Asymmetrical street canyons which are the most available street morphology type in tropical countries, have not received adequate attention.

5) How local climate zone (LCZ) classification approach could be used for assessing OTC in warm-humid climates require further exploration.

\section{Conclusion}

This bibliometric mapping of literature was performed in three main steps; 1 ) Bibliometric Search, 2) Scientometric Analysis, and 3) Content analysis to identify and compare specific research attention received by the studies of microclimate and outdoor thermal comfort (OTC) in warm humid urban public spaces. Both search results from the Scopus database, a) pertaining to all climatic regions (256 articles), and b) warm-humid climatic cities (34 articles) were analyzed separately. Article screening was carried out with inclusion and exclusion criteria with digital screening and manual screening. The advancement of the publications was analyzed by adapting scientometric analysis using the VOSviewer software which quantitatively visualizes the network of scientific literature. Search results were descriptively analyzed by scrutinizing their publication pattern, contributing countries, keywords, leading journals, and influential authors which shows the relationships among the selected articles creating a network using nodes and connections. The finalized 34 articles in warm humid climates were reviewed with Scientometric analysis to identify the most influential articles based on the normal citations. Consequently, it performed quantitative analysis on the related literature to identify knowledge distribution of the research areas, latest movement, evolution paths, and research gaps. The resultant 12 most influential articles identified by the highest normal citations, were reviewed conducting document analysis, and research trends for further advancement have been suggested on urban microclimate and thermal comfort of public spaces in tropical cities.

The results of the Scientometric analysis of the author keywords revealed that the current literature related to all climatic regions could be divided into five main research trends 1) urban heat gain and strategies using cooling materials, 2) simulation modeling in urban planning processes, 3) impact of urban morphology and vegetation on thermal perception, 4) effects of urban heat gain and cooling effects of green infrastructure, and 5) thermal adaptation in public space design. However, research in warm-humid climates requires further enhancement. The most recent research trend on investigating the influence of urban morphology has received $50 \%$ attention out of the total highest influential studies. Urban vegetation has received $33 \%$ with fluctuated attention and blue infrastructure received $8.3 \%$ as the lowest attention from the most influential studies conducted in warm-humid cities. This review identified four design components affecting urban biometeorology, namely; urban surfaces, morphology 
and geometry, green infrastructure, and blue infrastructure. OTC is highly influenced by local climate and urban design parameters. Therefore, this study recommends five research areas; the impact of blue infrastructure on OTC in local climates, heat mitigation strategies to overcome the issues related to use of reflective (high albedo) surface materials, vegetation configurations in street canyons taking wind flow into consideration, OTC improvements in asymmetrical street canyons, and finally how local climate zone (LCZ) classification approach could be used for assessing OTC in warm-humid climates.

Comprehensive content analysis, bibliographic coupling based on documents, co-occurrence of all-keywords, other proper methods performed by VOSviewer and search results from other credible databases are suggested for future research. The results of this study could motivate and direct interested scholars towards the potential and much-needed research areas in warm-humid cities. This method of study could be improved and applied to review previous studies and identify research gaps in specific research domains. Finally, proper investigations of the suggested areas will enable the enhancement of knowledge in the domain of urban microclimate and OTC in public spaces, thereby assisting the professionals in making planning and designing decisions thus improving thermal comfort and livability of urban spaces.

\section{Acknowledgements}

This work is supported by the Accelerating Higher Education Expansion and Development (AHEAD) - DOR Grant affiliation with Ministry of Higher Education \& University Grants Commission and funded by the World Bank.

Grant NO; Credit/Grant \#: 6026-LK/8743-LK (AHEAD/DOR/52).

\section{Conflicts of Interest}

The authors declare no conflicts of interest regarding the publication of this paper.

\section{References}

Acero, J. A., Koh, E. J., Pignatta, G., \& Norford, L. K. (2020). Clustering Weather Types for Urban Outdoor Thermal Comfort Evaluation in a Tropical Area. Theoretical and Applied Climatology, 139, 659-675. https://doi.org/10.1007/s00704-019-02992-9

Agarwal, A., Durairajanayagam, D., Tatagari, S., Esteves, S. C., Harlev, A., Henkel, R., Bashiri, A. et al. (2016). Bibliometrics: Tracking Research Impact by Selecting the Appropriate Metrics. Asian Journal of Andrology, 18, 296. https://doi.org/10.4103/1008-682X.171582

Algeciras, J. A. R., Consuegra, L. G., \& Matzarakis, A. (2016). Spatial-Temporal Study on the Effects of Urban Street Configurations on Human Thermal Comfort in the World Heritage City of Camagüey-Cuba. Building and Environment, 101, 85-101. https://doi.org/10.1016/j.buildenv.2016.02.026

Bartesaghi-Koc, C., Osmond, P., \& Peters, A. (2019). Spatio-Temporal Patterns in Green Infrastructure as Driver of Land Surface Temperature Variability: The Case of Sydney. International Journal of Applied Earth Observation and Geoinformation, 83, Article 
ID: 101903. https://doi.org/10.1016/j.jag.2019.101903

Broadbent, A. M., Coutts, A. M., Tapper, N. J., \& Demuzere, M. (2018). The Cooling Effect of Irrigation on Urban Microclimate during Heatwave Conditions. Urban Climate, 23, 309-329. https://doi.org/10.1016/j.uclim.2017.05.002

Chatzidimitriou, A., \& Yannas, S. (2015). Microclimate Development in Open Urban Spaces: The Influence of Form and Materials. Energy and Buildings, 108, 156-174. https://doi.org/10.1016/j.enbuild.2015.08.048

Chatzidimitriou, A., \& Yannas, S. (2017). Street Canyon Design and Improvement Potential for Urban Open Spaces; the Influence of Canyon Aspect Ratio and Orientation on Microclimate and Outdoor Comfort. Sustainable Cities and Society, 33, 85-101. https://doi.org/10.1016/j.scs.2017.05.019

Chow, W. T., Akbar, S. N. A. B. A., Heng, S. L., \& Roth, M. (2016). Assessment of Measured and Perceived Microclimates within a Tropical Urban Forest. Urban Forestry \& Urban Greening, 16, 62-75. https://doi.org/10.1016/j.ufug.2016.01.010

De Abreu-Harbich, L. V., Labaki, L. C., \& Matzarakis, A. (2015). Effect of Tree Planting Design and Tree Species on Human Thermal Comfort in the Tropics. Landscape and Urban Planning, 138, 99-109. https://doi.org/10.1016/j.landurbplan.2015.02.008

Deng, J. Y., \& Wong, N. H. (2020). Impact of Urban Canyon Geometries on Outdoor Thermal Comfort in Central Business Districts. Sustainable Cities and Society, 53, Article ID: 101966. https://doi.org/10.1016/j.scs.2019.101966

Doulos, L., Santamouris, M., \& Livada, I. (2004). Passive Cooling of Outdoor Urban Spaces. The Role of Materials. Solar Energy, 77, 231-249. https://doi.org/10.1016/j.solener.2004.04.005

Eck, N., \& Waltman, L. (2020). VOSviewer Manual. Leiden University's Centre.

Eliasson, I. (2000). The Use of Climate Knowledge in Urban Planning. Landscape and Urban Planning, 48, 31-44. https://doi.org/10.1016/S0169-2046(00)00034-7

Emmanuel, R., Rosenlund, H., \& Johansson, E. (2007). Urban Shading-A Design Option for the Tropics? A Study in Colombo, Sri Lanka. International Journal of Climatology: A Journal of the Royal Meteorological Society, 27, 1995-2004. https://doi.org/10.1002/joc.1609

Fabbri, K., Gaspari, J., Bartoletti, S., \& Antonini, E. (2020). Effect of Facade Reflectance on Outdoor Microclimate: An Italian Case Study. Sustainable Cities and Society, 54, Article ID: 101984. https://doi.org/10.1016/j.scs.2019.101984

Falasca, S., Ciancio, V., Salata, F., Golasi, I., Rosso, F., \& Curci, G. (2019). High Albedo Materials to Counteract Heat Waves in Cities: An Assessment of Meteorology, Buildings Energy Needs and Pedestrian Thermal Comfort. Building and Environment, 163, Article ID: 106242. https://doi.org/10.1016/j.buildenv.2019.106242

Fintikakis, N., Gaitani, N., Santamouris, M., Assimakopoulos, M., Assimakopoulos, D. N., Fintikaki, M., Doumas, P. et al. (2011). Bioclimatic Design of Open Public Spaces in the Historic Centre of Tirana, Albania. Sustainable Cities and Society, 1, 54-62. https://doi.org/10.1016/j.scs.2010.12.001

Fung, C. K., \& Jim, C. Y. (2020). Influence of Blue Infrastructure on Lawn Thermal Microclimate in a Subtropical Green Space. Sustainable Cities and Society, 52, Article ID: 101858. https://doi.org/10.1016/j.scs.2019.101858

Givoni, B. (1992). Comfort, Climate Analysis and Building Design Guidelines. Energy and Buildings, 18, 11-23. https://doi.org/10.1016/0378-7788(92)90047-K

Han, J., Zhang, G., Zhang, Q., Zhang, J., Liu, J., Tian, L., Moschandreas, D. J. et al. (2007). Field Study on Occupants' Thermal Comfort and Residential Thermal Environment in 
a Hot-Humid Climate of China. Building and Environment, 42, 4043-4050. https://doi.org/10.1016/j.buildenv.2006.06.028

Hernández-Torrano, D., Ibrayeva, L., Sparks, J., Lim, N., Clementi, A., Almukhambetova, A., Muratkyzy, A. et al. (2020). Mental Health and Well-Being of University Students: A Bibliometric Mapping of the Literature. Frontiers in Psychology, 11, 1226. https://doi.org/10.3389/fpsyg.2020.01226

Holst, J., \& Mayer, H. (2011). Impacts of Street Design Parameters on Human-Bio Meteorological Variables. Meteorologische Zeitschrift, 20, 541. https://doi.org/10.1127/0941-2948/2011/0254

Hoppe, P. (1999). The Physiological Equivalent Temperature-A Universal Index for the Bio Meteorological Assessment of the Thermal Environment. International Journal of Biometeorology, 43, 71-75. https://doi.org/10.1007/s004840050118

Hsieh, C. M., Jan, F. C., \& Zhang, L. (2016). A Simplified Assessment of How Tree Allocation, Wind Environment, and Shading Affect Human Comfort. Urban Forestry \& Urban Greening, 18, 126-137. https://doi.org/10.1016/j.ufug.2016.05.006

Jin, R., Zou, P. X., Piroozfar, P., Wood, H., Yang, Y., Yan, L., \& Han, Y. (2019). A Science Mapping Approach Based Review of Construction Safety Research. Safety Science, 113, 285-297. https://doi.org/10.1016/j.ssci.2018.12.006

Johansson, E., \& Emmanuel, R. (2006). The Influence of Urban Design on Outdoor Thermal Comfort in the Hot, Humid City of Colombo, Sri Lanka. International Journal of Biometeorology, 51, 119-133. https://doi.org/10.1007/s00484-006-0047-6

Johansson, E., Spangenberg, J., Gouvêa, M. L., \& Freitas, E. D. (2013). Scale-Integrated Atmospheric Simulations to Assess Thermal Comfort in Different Urban Tissues in the Warm Humid Summer of São Paulo, Brazil. Urban Climate, 6, 24-43. https://doi.org/10.1016/j.uclim.2013.08.003

Johansson, E., Yahia, M. W., Arroyo, I., \& Bengs, C. (2018). Outdoor Thermal Comfort in Public Space in Warm-Humid Guayaquil, Ecuador. International Journal of Biometeorology, 62, 387-399. https://doi.org/10.1007/s00484-017-1329-x

Kawshalya, L., Weerasinghe, U., \& Chandrasekara, D. (2020). Fear of Crime in Urban Environments: A Bibliometric Mapping of the Literature. In 2020 from Innovation to Impact (FITI) (pp. 1-6). IEEE.

https://ieeexplore.ieee.org/document/9424901/authors\#authors https://doi.org/10.1109/FITI52050.2020.9424901

Kumar, P., \& Sharma, A. (2021). Assessing the Thermal Comfort Conditions in Open Spaces: A Transversal Field Survey on the University Campus in India. International Journal of Built Environment and Sustainability, 8, 77-92. https://doi.org/10.11113/ijbes.v8.n3.786

Lai, D., Liu, W., Gan, T., Liu, K., \& Chen, Q. (2019). A Review of Mitigating Strategies to Improve the Thermal Environment and Thermal Comfort in Urban Outdoor Spaces. Science of the Total Environment, 661, 337-353. https://doi.org/10.1016/j.scitotenv.2019.01.062

Lamarca, C., Qüense, J., \& Henríquez, C. (2018). Thermal Comfort and Urban Canyons Morphology in Coastal Temperate Climate, Concepción, Chile. Urban Climate, 23, 159-172. https://doi.org/10.1016/j.uclim.2016.10.004

Lau, K. K. L., Chung, S. C., \& Ren, C. (2019). Outdoor Thermal Comfort in Different Urban Settings of Sub-Tropical High-Density Cities: An Approach of Adopting Local Climate Zone (LCZ) Classification. Building and Environment, 154, 227-238. https://doi.org/10.1016/j.buildenv.2019.03.005

Lee, H., \& Mayer, H. (2018). Maximum Extent of Human Heat Stress Reduction on Build- 
ing Areas Due to Urban Greening. Urban Forestry \& Urban Greening, 32, 154-167. https://doi.org/10.1016/j.ufug.2018.04.010

Lee, H., Mayer, H., \& Chen, L. (2016). Contribution of Trees and Grasslands to the Mitigation of Human Heat Stress in a Residential District of Freiburg, Southwest Germany. Landscape and Urban Planning, 148, 37-50.

https://doi.org/10.1016/j.landurbplan.2015.12.004

Lee, H., Mayer, H., \& Kuttler, W. (2020). Impact of the Spacing between Tree Crowns on the Mitigation of Daytime Heat Stress for Pedestrians inside EW Urban Street Canyons under Central European Conditions. Urban Forestry \& Urban Greening, 48, Article ID: 126558. https://doi.org/10.1016/j.ufug.2019.126558

Lin, T. P., Matzarakis, A., Hwang, R. L., \& Huang, Y. C. (2010). Effect of Pavements Albedo on Long-Term Outdoor Thermal Comfort (p. 497). Berichte des MeteorologischenInstituts der Albert-Ludwigs-Universität Freiburg.

Lin, T. P., Tsai, K. T., Hwang, R. L., \& Matzarakis, A. (2012). Quantification of the Effect of Thermal Indices and Sky View Factor on Park Attendance. Landscape and Urban Planning, 107, 137-146. https://doi.org/10.1016/j.landurbplan.2012.05.011

Mahmoud, H., Ghanem, H., \& Sodoudi, S. (2021). Urban Geometry as an Adaptation Strategy to Improve the Outdoor Thermal Performance in Hot Arid Regions: Aswan University as a Case Study. Sustainable Cities and Society, 71, Article ID: 102965. https://doi.org/10.1016/j.scs.2021.102965

Manteghi, G., Mostofa, T., \& Noor, M. P. B. M. (2020). A Field Investigation on the Impact of the Wider Water Body On-Air, Surface Temperature and Physiological Equivalent Temperature at Malacca Town. International Journal of Environmental Science and Development, 11, 286-291. https://doi.org/10.18178/ijesd.2020.11.6.1264

Matzarakis, A., Mayer, H., \& Iziomon, M. G. (1999). Applications of a Universal Thermal Index: Physiological Equivalent Temperature. International Journal of Biometeorology, 43, 76-84. https://doi.org/10.1007/s004840050119

Mayer, H., \& Höppe, P. (1987). Thermal Comfort of Man in Different Urban Environments. Theoretical and Applied Climatology, 38, 43-49. https://doi.org/10.1007/BF00866252

Mayer, H., Holst, J., Dostal, P., Imbery, F., \& Schindler, D. (2008). Human Thermal Comfort in Summer within an Urban Street Canyon in Central Europe. Meteorologische Zeitschrift, 17, 241-250. https://doi.org/10.1127/0941-2948/2008/0285

Meng, L., Wen, K. H., Brewin, R., \& Wu, Q. (2020). Knowledge Atlas on the Relationship between Urban Street Space and Residents' Health-A Bibliometric Analysis Based on VOSviewer and CiteSpace. Sustainability, 12, 2384. https://doi.org/10.3390/su12062384

Mongeon, P., \& Paul-Hus, A. (2016). The Journal Coverage of Web of Science and Scopus: A Comparative Analysis. Scientometrics, 106, 213-228.

https://doi.org/10.1007/s11192-015-1765-5

Mora, L., Bolici, R., \& Deakin, M. (2017). The First Two Decades of Smart-City Research: A Bibliometric Analysis. Journal of Urban Technology, 24, 3-27. https://doi.org/10.1080/10630732.2017.1285123

Morakinyo, T. E., \& Lam, Y. F. (2016). Simulation Study on the Impact of Tree-Configuration, Planting Pattern and Wind Condition on Street-Canyon's Micro-Climate and Thermal Comfort. Building and Environment, 103, 262-275. https://doi.org/10.1016/j.buildenv.2016.04.025

Morakinyo, T. E., Kong, L., Lau, K. K. L., Yuan, C., \& Ng, E. (2017). A Study on the Impact of Shadow-Cast and Tree Species on In-Canyon and Neighborhood's Thermal Comfort. Building and Environment, 115, 1-17. 
https://doi.org/10.1016/j.buildenv.2017.01.005

Morakinyo, T. E., Lau, K. K. L., Ren, C., \& Ng, E. (2018). Performance of Hong Kong's Common Trees Species for Outdoor Temperature Regulation, Thermal Comfort and Energy Saving. Building and Environment, 137, 157-170. https://doi.org/10.1016/j.buildenv.2018.04.012

Mouada, N., Zemmouri, N., \& Meziani, R. (2019). Urban Morphology, Outdoor Thermal Comfort and Walkability in Hot, Dry Cities: Case Study in Sidi Okba, Algeria. International Review for Spatial Planning and Sustainable Development, 7, 117-133. https://doi.org/10.14246/irspsda.7.1_117

Muniz-Gäal, L. P., Pezzuto, C. C., de Carvalho, M. F. H., \& Mota, L. T. M. (2020). Urban Geometry and the Microclimate of Street Canyons in Tropical Climate. Building and Environment, 169, Article ID: 106547. https://doi.org/10.1016/j.buildenv.2019.106547

Ng, E., Chen, L., Wang, Y., \& Yuan, C. (2012). A Study on the Cooling Effects of Greening in a High-Density City: An Experience from Hong Kong. Building and Environment, 47, 256-271. https://doi.org/10.1016/j.buildenv.2011.07.014

Nikolopoulou, M., \& Steemers, K. (2003). Thermal Comfort and Psychological Adaptation as a Guide for Designing Urban Spaces. Energy and Buildings, 35, 95-101. https://doi.org/10.1016/S0378-7788(02)00084-1

Peponi, A., \& Morgado, P. (2020). Smart and Regenerative Urban Growth: A Literature Network Analysis. International Journal of Environmental Research and Public Health, 17, 2463. https://doi.org/10.3390/ijerph17072463

Ruiz, M. A., \& Correa, E. N. (2015). Adaptive Model for Outdoor Thermal Comfort Assessment in an Oasis City of Arid Climate. Building and Environment, 85, 40-51. https://doi.org/10.1016/j.buildenv.2014.11.018

Setaih, K., Hamza, N., \& Townshend, T. (2013). Assessment of Outdoor Thermal Comfort in Urban Microclimate in Hot Arid Areas. In 13th International Conference of International Building Performance Simulation Association, Chambery, France (pp. 3153-3160).

Shareef, S., \& Abu-Hijleh, B. (2020). The Effect of Building Height Diversity on Outdoor Microclimate Conditions in Hot Climate. A Case Study of Dubai-UAE. Urban Climate, 32, Article ID: 100611. https://doi.org/10.1016/j.uclim.2020.100611

Sharmin, T., Steemers, K., \& Matzarakis, A. (2015). Analysis of Microclimatic Diversity and Outdoor Thermal Comfort Perceptions in the Tropical Megacity Dhaka, Bangladesh. Building and Environment, 94, 734-750.

https://doi.org/10.1016/j.buildenv.2015.10.007

Shashua-Bar, L., Pearlmutter, D., \& Erell, E. (2011). The Influence of Trees and Grass on Outdoor Thermal Comfort in a Hot-Arid Environment. International Journal of Climatology, 31, 1498-1506. https://doi.org/10.1002/joc.2177

Spagnolo, J., \& De Dear, R. (2003). A Field Study of Thermal Comfort in Outdoor and Semi-Outdoor Environments in Subtropical Sydney Australia. Building and Environment, 38, 721-738. https://doi.org/10.1016/S0360-1323(02)00209-3

Stewart, I. D., \& Oke, T. R. (2012). Local Climate Zones for Urban Temperature Studies. Bulletin of the American Meteorological Society, 93, 1879-1900. https://doi.org/10.1175/BAMS-D-11-00019.1

Su, H. N., \& Lee, P. C. (2010). Mapping Knowledge Structure by Keyword Co-Occurrence: A First Look at Journal Papers in Technology Foresight. Scientometrics, 85, 65-79. https://doi.org/10.1007/s11192-010-0259-8

Taleghani, M. (2018). Outdoor Thermal Comfort by Different Heat Mitigation Strategies-A Review. Renewable and Sustainable Energy Reviews, 81, 2011-2018. 
https://doi.org/10.1016/j.rser.2017.06.010

Taleghani, M., Kleerekoper, L., Tenpierik, M., \& Van Den Dobbelsteen, A. (2015). Outdoor Thermal Comfort within Five Different Urban Forms in the Netherlands. Building and Environment, 83, 65-78. https://doi.org/10.1016/j.buildenv.2014.03.014

Tanudjaja, I., \& Kow, G. Y. (2018). Exploring Bibliometric Mapping in NUS Using BibExcel and VOSviewer.

Teshnehdel, S., Akbari, H., Di Giuseppe, E., \& Brown, R. D. (2020). Effect of Tree Cover and Tree Species on Microclimate and Pedestrian Comfort in a Residential District in Iran. Building and Environment, 178, Article ID: 106899.

https://doi.org/10.1016/j.buildenv.2020.106899

Thani, S. K. S. O., Mohamad, N. H. N., \& Abdullah, S. M. S. (2013). The Influence of Urban Landscape Morphology on the Temperature Distribution of Hot-Humid Urban Centre. Procedia-Social and Behavioral Sciences, 85, 356-367. https://doi.org/10.1016/j.sbspro.2013.08.365

Van Eck, N. J., \& Waltman, L. (2019). VOSviewer Manual. University of Leiden. https://www.vosviewer.com/documentation/Manual_VOSviewer_1.6.13.pdf

Venhari, A. A., Tenpierik, M., \& Taleghani, M. (2019). The Role of Sky View Factor and Urban Street Greenery in Human Thermal Comfort and Heat Stress in a Desert Climate. Journal of Arid Environments, 166, 68-76. https://doi.org/10.1016/j.jaridenv.2019.04.009

Wai, K. M., Xiao, L., \& Tan, T. Z. (2021). Improvement of the Outdoor Thermal Comfort by Water Spraying in a High-Density Urban Environment under the Influence of a Future (2050) Climate. Sustainability, 13, 7811. https://doi.org/10.3390/su13147811

Waltman, L., Eck, N. J. V., \& Noyons, E. C. (2010). A Unified Approach to Mapping and Clustering of Bibliometric Networks. Journal of Informetrics, 4, 629-635.

https://doi.org/10.1016/j.joi.2010.07.002

Xue, J., You, R., Liu, W., Chen, C., \& Lai, D. (2020). Applications of Local Climate Zone Classification Scheme to Improve Urban Sustainability: A Bibliometric Review. Sustainability, 12, 8083. https://doi.org/10.3390/su12198083

Yahia, M. W., \& Johansson, E. (2014). Landscape Interventions in Improving Thermal Comfort in the Hot Dry City of Damascus, Syria-The Example of Residential Spaces with Detached Buildings. Landscape and Urban Planning, 125, 1-16. https://doi.org/10.1016/j.landurbplan.2014.01.014

Yahia, M. W., Johansson, E., Thorsson, S., Lindberg, F., \& Rasmussen, M. I. (2018). Effect of Urban Design on Microclimate and Thermal Comfort Outdoors in Warm-Humid Dar es Salaam, Tanzania. International Journal of Biometeorology, 62, 373-385.

https://doi.org/10.1007/s00484-017-1380-7

Zaki, S. A., Toh, H. J., Yakub, F., Mohd Saudi, A. S., Ardila-Rey, J. A., \& Muhammad-Sukki, F. (2020). Effects of Roadside Trees and Road Orientation on Thermal Environment in a Tropical City. Sustainability, 12, 1053.

https://doi.org/10.3390/su12031053

Zhao, L., \& Shen, L. (2018). Bibliometric Analysis and Visualization on International Mobile Library Research Output, 2007-2016. In 2018 Chinese Control and Decision Conference (CCDC) (pp. 1902-1907). IEEE. https://doi.org/10.1109/CCDC.2018.8407437

Zhao, T. F., \& Fong, K. F. (2017). Characterization of Different Heat Mitigation Strategies in Landscape to Fight against Heat Island and Improve Thermal Comfort in Hot-Humid Climate (Part I): Measurement and Modelling. Sustainable Cities and Society, 32, 523-531. https://doi.org/10.1016/j.scs.2017.03.025 